Justyna Kiliańczyk-Zięba (1) http://orcid.org/0000-0001-6592-4747

Uniwersytet Jagielloński, Kraków

justyna.kilianczyk-zieba@uj.edu.pl

\title{
Wydawnicze skamieliny. Późne edycje bestsellerów jako źródło informacji o kształcie wizualnym pierwszego wydania tekstu
}

\begin{abstract}
Printed Fossils. Late Editions of Bestsellers as a Source of Information on the Typographic Shape of the First Edition of a Text
\end{abstract}

One of the important problems studied by book historians is the fate of those titles and editions that have not survived to our times. These were oftentimes the most popular and most frequently purchased publications, very vulnerable to destruction exactly due to their popularity. The information about lost editions usually comes from the old book lists (inventories and catalogues of early modern book collections, $18^{\text {th }}$ and $19^{\text {th }}$ century bibliographies), as well as from mentions by various authors. Justyna Kiliańczyk-Zięba shows that information about the existence and typographical shape of the lost editions is also to be found in preserved editions which were published decades or even centuries after the first editions. The study draws on bibliographic research and editorial work carried out over several years. Its aim is to present a methodology that allows the layout of the today unknown first print of Fortuna abo Szczęście by Stanislaw of Bochnia to be reconstructed with high probability.

Keywords: Cracow printing, lost books, typography and layout, popular literature 
Historycy książki od lat powtarzają, że materiały drukowane z pierwszych wieków istnienia „czarnej sztuki”, które są nam dostępne we współczesnych bibliotekach, to tylko ułamek dawnej produkcji wydawniczej. Co więcej - że charakter zachowanych księgozbiorów nie odzwierciedla repertuaru dawnych drukarni, że te tytuły, które typografowie tłoczyli w wysokich nakładach i powtarzanych edycjach, a więc książki, które ówcześnie były bestsellerami, w przytłaczającej i trudnej do oszacowania większości nie zachowały się do naszych czasów.

Liczne publikacje, posługujące się rozmaitymi metodologiami, przyniosły w ostatnich latach wiele przekonujących (albo przynajmniej wartych rozważenia) argumentów na poparcie tych twierdzeń. Nie będę ich jednak tutaj przytaczać1. Nie ma tutaj także miejsca na omówienie zespołu czynników, które determinowały losy poszczególnych egzemplarzy, tytułów czy wydań wyprodukowanych w pierwszych stuleciach istnienia „czarnej sztuki”2. Warto może tylko krótko przypomnieć, że szanse dawnego druku na przetrwanie określało kilka jego cech. W pierwszej kolejności cechy fizyczne, łatwo uchwytne: rozmiar i wiek druku oraz język powielonego tekstu. Najłatwiej - jako

${ }^{1}$ Szacunki dotyczące zaginionych edycji przedstawiają na przykład J. Green, F. McIntyre, P. Needham, The Shape of Incunable Survival and Statistical Estimation of Lost Editions, „The Papers of the Bibliographical Society of America” 105 (2011), no. 2, s. 141-175; J. Green, F. McIntyre, Lost Incunable Editions. Closing in on an estimate, w: Lost Books. Reconstructing the Print World of Pre-Industrial Europe, ed. F. Bruni, A. Pettegree, Leiden 2016, s. 55-72. Zob. też: J. Green, Databases, Book Survival and Early Printing, „Wolfenbütteler Notizen zur Buchgeschichte” 40 (2015), s. $35-47$.

${ }^{2}$ O najważniejszych czynnikach zwiększających szansę egzemplarza dawnej edycji na przetrwanie przez wieki piszą: N. Harris, Marin Sanudo, Forerunner of Melzi, part 1, „La Bibliofilia” (1993), s. 12-29; P. Needham, The Late Use of Incunables and the Paths of Book Survival, "Wolfenbütteler Notizen zur Buchgeschichte" 29 (2004), H. 2, s. 39-41; G. Proot, Survival Factors in Seventeenth-Century Hand-Press Books Published in the Southern Netherlands. The Importance of Sheet Counts, Sammelbände and the Role of Institutional Collections, w: Lost Books..., s. $160-201$. 
przedmioty drobne i bez większej wartości materialnej - ginęły druki wytłoczone na niewielkiej liczbie arkuszy: plakaty, cienkie broszury, książeczki w małych formatach. Wiadomo też, że druki po łacinie miały większe szanse na przetrwanie niż te w językach narodowych. Prowadząc badania statystyczne, bibliografowie zauważyli także, że jeśli książka miała wiele wydań, znamy dziś raczej edycje późniejsze niż wcześniejsze tego samego tytułu.

Obok cech fizycznych druku także charakter tekstu w nim wytłoczonego (a zarazem adres czytelniczy i przeznaczenie) określał jego los. Wszelkie druki użytkowe (podręczniki, poradniki, modlitewniki, wzorniki) czy wydawnictwa rozrywkowe (nowiny, romanse, drukowane gry), które trafiały do coraz szerszej w XV i XVI wieku grupy odbiorców, ginęły szczególnie łatwo. Jeśli druk był drobny (i tani), jeśli był wytłoczony po polsku, niemiecku czy włosku, jeśli udostępniał tekst interesujący nie tylko dla elity intelektualnej, przyzwyczajonej do obcowania z księgami, ale i uczniów, gospodarzy czy kupców, był praktycznie skazany na zagładę. Pokreślone, wytarte i brudne książki niewątpliwie trafiały w końcu „molom na pokarm albo na trąbki do apteki”. Podręczniki uczące zasad gramatyki lub rachunków, poradniki dla opiekunów koni, romanse, przygody Marchołta itd. po prostu czytane i używane były intensywnie, czasem codziennie, często przez więcej niż jedną osobę. Wyrzucano je, gdy nie były już potrzebne; wypadające karty pożytkowano na rozmaite sposoby; bardzo zniszczone egzemplarze zastępowano wydrukowanymi niedawno, czasem przynoszącymi tekst poprawiony czy poszerzony.

Książki te nieczęsto też trafiały do bibliotek instytucji - uniwersytetów czy klasztorów - i to również jest jedną z przyczyn, dla których dziś stanowią wielką rzadkość. Jeśli możemy niektóre z nich wziąć do ręki w czytelniach bibliotek czy muzeów, tę szczęśliwą okoliczność zwykle zawdzięczamy temu, że pierwsi właściciele kazali owe książeczki czy jednostronnie zadrukowane arkusze oprawić razem $\mathrm{z}$ innymi niedużymi drukami albo rękopisami. Powstawały w ten sposób klocki introligatorskie i masywne woluminy, zdolne skuteczniej niż drobne publikacje opierać się niszczącemu działaniu czasu 
i intensywnemu użytkowaniu ${ }^{3}$. Czasem znamy też ślady książek pojedyncze karty czy składki (zwykle środkowe) z obszerniejszych publikacji. Nieraz tekst wydrukowany na nich udaje się zidentyfikować, przynajmniej opatrzyć tytułem. W takich wypadkach dawna książka często staje się uchwytna we współczesnym katalogu jako egzemplarz tylko dlatego, że nie trafiła do rąk czytelnika w czasie, gdy ją drukowano. Te ułomki to bowiem zwykle makulatura wydobyta $\mathrm{z}$ dawnych opraw - zbywające arkusze (czasem z korektą), które drukarze sprzedawali introligatorom. Papier bowiem był zbyt drogi, by go po prostu wyrzucać ${ }^{4}$.

"Ocaleńcy” są katalogowani, notuje się też ich obecność w bibliografiach. Jednak analizując te rejestracje, koniecznie pamiętać trzeba, że nie mogą one dać nam pełnego wyobrażenia o repertuarze pierwszych oficyn ani o tym, które tytuły drukowano najczęściej i w wysokich nakładach, bo atrakcyjne były dla szerokiej (toutes proportions gardées) grupy odbiorców.

O tym, że - paradoksalnie - najmniej wiemy o książkach najpopularniejszych, podczas gdy w stosunkowo dużej liczbie kopii zachowały się edycje przeznaczone dla elitarnej grupy czytelników księgi uczone, obszerne, kosztowne - świadczą nie tylko obserwacje na temat mechanizmów trwania i ginięcia dawnych druków, które przytoczyłam na poprzednich stronach. Potwierdzają to również studia nad spektakularnymi przedsięwzięciami wydawniczymi XV czy XVI wieku, książkami takimi jak Liber Chronicarum Hartmanna Schedla (1493), De revolutionibus Mikołaja Kopernika (1543) czy De humani corporis fabrica Andreasa Vesaliusa (1543). Niezależnie od wysokości nakładów, w których były owe dzieła tłoczone (szacuje się, że łacińską wersję Kroniki norymberskiej wydrukowano w blisko 1300 kopiach, podczas gdy traktat Kopernika wyszedł zapewne w 500),

3 Ibidem, s. 190-192.

${ }^{4}$ K. Piekarski, Fragmenty czterech nieznanych wydań „Marchołta”, „Pamiętnik Literacki” 32 (1935), s. 481-520; idem, Fragmenty dwu zaginionych dialogów Mikołaja Reja, „Przegląd Współczesny” 6 (1923), nr 15, s. 1-16. 
zachowała się duża liczba ich egzemplarzy. We współczesnych kolekcjach znajduje się co najmniej 889 Kronik Schedla po łacinie, około 270 egzemplarzy $O$ obrotach... w pierwszym wydaniu i ponad 300 kopii atlasu anatomicznego Vesaliusa z 1543 roku $^{5}$.

Tymczasem wiele tytułów i wiele publikacji, po których nie został ślad w postaci zadrukowanych kart, możemy tylko odtwarzać na podstawie źródeł historycznych. Uświadamiają nam one niegdysiejsze istnienie licznych książek, często bestsellerów, produkowanych w tysiącach kopii. Źródła, na podstawie których druki owe można przywracać współczesnej refleksji badawczej, to w pierwszym rzędzie materiały archiwalne, na przykład katalogi, listy, rachunki z epoki, przywileje, akta sądowe, a zwłaszcza inwentarze (szczególnie - inwentarze kupców handlujących w niedużych ośrodkach czy spisy książek z kramów księgarzy i introligatorów) ${ }^{6}$. W moim tekście chciałabym się jednak skupić na innej kategorii źródeł: samych starych drukach przechowanych we współczesnych kolekcjach. One również bywają świadkami istnienia kiedyś książek dziś fizycznie niedostępnych. A nawet - jak postaram się pokazać - pozwalają rekonstruować kształt edytorski zaginionych publikacji.

5 Zob. Ch. Reske, Die Produktion der Schedelschen Weltchronik in Nürnberg = The Production of Schedel's Nuremberg Chronicle, Wiesbaden 2000, s. 186; O. Gingerich, Książka, której nikt nie przeczytał, przeł. J. Włodarczyk, Warszawa 2004, s. 132; D. Margócsy, M. Somos, S.N. Joffe, The Fabrica of Andreas Vesalius. A Worldwide Descriptive Census, Ownership, and Annotations of the 1543 and 1555 Editions, Leiden 2018, s. 3, 8.

6 Zob. na przykład A. Chmiel, Inwentarz rzeczy introligatora krakowskiego Macieja Przywilckiego z roku 1587, „Silva Rerum” 4 (1928), s. 175-180; J. Kiliańczyk-Zięba, The Book Inventory of the Sixteenth-Century Krakow Bookbinder, Maciej Przywilcki, w: Documenting the Early Modern Book World. Inventories and Catalogues in Manuscript and Print, ed. M. Walsby, N. Constantinidou, Leiden 2013, s. 263-282; E. Różycki, Inwentarz książek kuśnierza Wojciecha Charajowicza ze Lwowa z początku XVII wieku, „Roczniki Biblioteczne” 36 (1992), z. 1-2, s. 267278. A. Lewicka-Kamińska, Inwentarz księgarni Andrzeja Cichończyka w Jarosławiu $z$ r. 1621, „Roczniki Biblioteczne” 5 (1961), s. 253-299. 
Cennych informacji o zaginionych publikacjach dostarczają strony tytułowe, dedykacje i przedmowy zachowanych druków, wytłoczonych czasem znacznie później niż ich przodkowie. Przede wszystkim dlatego, że dawni typografowie wykorzystywali komunikacyjny potencjał ramy wydawniczej, by zalecać czytelnikom swoje produkty jako poprawione, ulepszone, rozszerzone, czyli poszukiwane przez czytelników ${ }^{7}$. Na stronach tytułowych dawnych bestsellerów często tłoczono formuły reklamujące poszczególne wydania jako drukowane „z poprawą, słowy wyborniejszemi”, „z dokładem”, „rozszyrzone”, „teraz znowu poprawione”. Zdarza się, że nie znamy starszych, „niepoprawionych" edycji tekstów, które drukarze oddawali w ręce czytelników, opatrując swe prace tego rodzaju zachętami. Jednak zapisy na stronach tytułowych przedruków nie pozostawiają wątpliwości co do tego, że istniały wcześniejsze wydania. Przykładem może być dydaktyczny poemat Macieja Wirzbięty Gospodarstwo dla młodych a nowotnych gospodarzów. $\mathrm{O}$ tym, że opublikowany pod poradnikowym tytułem wykład o cnotliwej, oszczędnej egzystencji był wśród współczesnych popularny, świadczą jego ponawiane wznowienia: dziś możemy wziąć do ręki egzemplarze aż czterech wydań tłoczonych w kilkuletnich odstępach: $\mathrm{z}$ roku 1596, około 1598, z lat około 1606-1608 i z roku około $1619^{8}$. Ale najstarszy ze znanych dziś egzemplarzy wcale nie należał do pierwszego wydania Gospodarstwa. Parenetyczny poemat Wirzbięty musiał mieć co najmniej jedną jeszcze wcześniejszą edycję: na stronie tytułowej książeczki z 1596 roku znalazła się formuła "teraz na ten Nowy Rok poprawione i rozszyrzone”.

Komunikaty ze stron tytułowych znajdują czasem potwierdzenie w informacjach $\mathrm{z}$ innych miejsc druku, zwykle we wzmiankach z dedykacji i przedmów. Na przykład Sprawy abo historyje znacznych

${ }^{7}$ R. Ocieczek, O różnych aspektach badań literackiej ramy wydawniczej w książkach dawnych, w: O literackiej ramie wydawniczej $w$ ksiązkach dawnych, red. R. Ocieczek, Katowice 1990, s. 7-20; G. Genette, Paratexts. Thresholds of Interpretation, trans. J.E. Lewin, Cambridge 1997.

8 Zob. J. Sokolski, Wstęp, w: M. Wirzbięta, Gospodarstwo dla młodych a nowotnych gospodarzów, przygotował J. Sokolski, Wrocław 1989, s. 24-25. 
niewiast Erazma Otwinowskiego Aleksy Rodecki wypuścił w świat w 1589 roku, tłocząc na stronie tytułowej książeczki zwyczajową formułę „krótko zebrane i znowu wydane”. Z kolei w przedmowie „Do Czytelnika pobożnego" autor pisał o popularności dzieła, skromnie utrzymując, że jego powtórna edycja powstała, by zaspokoić nalegania publiczności: „Iż pierwszego przed kilkiem lat tych książek wydania, Czytelniku łaskawy, już dawno nie zstało, przeto za upominaniem niektórych pewnych osób, którzy to za potrzebną rozumieli, aby znowu te książki wydane były, teraz je z poprawą ich w imię Pańskie znowu wypuszczam..."9.

W dedykacjach i przedmowach informacje o istnieniu poprzednich wydań danego tekstu wiążą się najczęściej z tego rodzaju zapewnieniami, stanowiącymi zarazem zalecenie książki; przedstawiają ją bowiem jako poszukiwaną, implikując jej czytelniczą atrakcyjność. Zdarza się jednak, że drukarze przedrukowywali dawne parateksty, jakby nie uznając ich dezaktualizacji. Dzięki temu zyskujemy nie tylko informacje o istnieniu wcześniejszych edycji tekstu, którego wydanie możemy wziąć do ręki, ale i dowiadujemy się sporo o okolicznościach powstania tekstu czy zaginionej dziś edycji. Na przykład Catonis disticha moralia [...] Katonowe wiersze podwójne dobrych obyczajów uczace w opracowaniu Sebastiana Fabiana Klonowica znamy z unikatowego egzemplarza edycji, którą Sebastian Sternacki wydrukował w Rakowie między 1603 a 1623 rokiem. Jednak popularny podręcznik do nauki łaciny i moralności w przekładzie Acernusa na pewno nie ukazał się pierwszy raz dopiero po śmierci poety (Klonowic zmarł w 1602 roku). Siedemnastowieczna edycja jest przedrukiem starszego wydania Katonowych wierszy podwójnych, które pierwszy raz wydrukowano w 1588 roku. Świadczy o tym stara (sprzed około dwudziestu lat) dedykacja dystychów, którą powtórzono

9 E. Otwinowski, Pisma poetyckie, wyd. P. Wilczek (Biblioteka Pisarzy Staropolskich, t. 15), Warszawa 1999, s. 41. Unikat Spraw... posiada Biblioteka Kórnicka PAN, sygn. Cim. Qu. 2646. Por. A. Kawecka-Gryczowa, Ariańskie oficyny wydawnicze Rodeckiego i Sternackiego. Dzieje i bibliografia, Wrocław 1974, nr 51, s. 169. 
w siedemnastowiecznym wydaniu. Klonowic ofiarował w niej swoją pracę Jerzemu Mniszchowi, małoletniemu synowi Mikołaja, starosty łukowskiego, dodając datę 8 kwietnia 1588 roku $^{10}$. Można się także domyślać, że pierwodruk Katonowych wierszy podwójnych tłoczono w krakowskim zakładzie Aleksego Rodeckiego: Sebastian Sternacki (drukarz zachowanej w jednym egzemplarzu siedemnastowiecznej edycji) odziedziczył drukarnię i część repertuaru wydawniczego po teściu, Rodeckim. Zaś o Klonowicu wiemy, że już około 1588 roku był klientem oficyny Aleksego ${ }^{11}$. Dedykacja tej niedużej książki staje się więc źródłem wiadomości o dacie i miejscu ukazania się niezachowanego do dziś pierwodruku.

Utrzymywanie dawnych przedmów w nowych wydaniach było obyczajem rozpowszechnionym, ale jego motywacje trudne są dziś do uchwycenia. W wypadku Katonowych wierszy zachowanie starej przedmowy w nowym wydaniu robi wrażenie pewnego automatyzmu - jakby zecer złożył druk, spoglądając na egzemplarz edycji dawniejszej, może nawet pierwszej, i kopiował wszystkie jego elementy, także - zdezaktualizowaną przedmowę. Mniej prawdopodobne wydaje się, że powtórzenie dedykacji było zabiegiem celowym, że na przykład doceniono potencjał reklamowy dedykacji podpisanej przez znanego poetę albo że Dystychy Katona zrosły się w miarę upływu lat i wydań z nazwiskami Klonowica i Mniszcha.

Inaczej - jako świadomy gest - jawi się powtórzenie dedykacji $\mathrm{z}$ editio princeps w kolejnym wydaniu Fortuny albo Szcześcia Stanisława z Bochnie, książki, z której można było przepowiadać przyszłość. Najstarsze uchwytne materialnie wydanie tej pozycji znamy z unikatowej kopii wydrukowanej w Krakowie przez Łazarza Andrysowica w latach 1561-1577, którą odkryłam w Bayerische Staatsbibliothek w Monachium ${ }^{12}$. Jednak drukując Fortunę, Andrysowic

${ }^{10}$ Ibidem, poz. 98, s. 206 (egz. Biblioteki Zakładu Narodowego im Ossolińskich we Wrocławiu, sygn. XVII.7501.II).

11 Ibidem, s. 38-39, s. 159-160.

12 Egzemplarz Bayerische Staatsbibliothek, sygn. Res. 2 Phys.m.7. Datę 1561 zaproponowano na podstawie analizy stopnia zużycia drzeworytów w tomie. W dru- 
powielił elementy ramy wydawniczej jej pierwszego wydania, między innymi dedykację drukarza Hieronima Wietora z 1532 roku. Wietor, mistrz autopromocji, w krótkim tekście wspominał, że przygotowanie bogato ilustrowanej książki było niezwykle kosztowne, że autorem jest kapelan królewski Stanisław z Bochnie i że proponowane w niej wróżby to tylko niewinna zabawa. Swą nowo wytłoczoną książkę drukarz darował samemu królowi Zygmuntowi Staremu - żadnej innej ze swych publikacji nie przypisał, o ile wiemy, osobie tak wysoko postawionej ${ }^{13}$. Łazarz, powtarzając tę dedykację, wykorzystywał jej niewątpliwy reklamowy potencjał. Przedrukowując list dedykacyjny Wietora, umożliwił także precyzyjne datowanie pierwodruku i wskazał miejsce jego produkcji.

O tym, że kolekcję wróżb Stanisława z Bochnie drukowano w Krakowie, u Wietora, na początku lat 30. XVI wieku, wiadomo było, zanim odnalazł się w Monachium unikatowy egzemplarz edycji Łazarza Andrysowica. Znane były bowiem, po pierwsze, kopie dwóch siedemnastowiecznych wydań Fortuny, po drugie - osiemnastowieczne egzemplarze przeróbki dzieła Stanisława Kleryki (dokonał jej Jan Gawiński) oraz (po trzecie) ślady recepcji zbioru za granicami Królestwa Polskiego ${ }^{14}$. Posługując się tymi materiałami, próbowałam kiedyś odtworzyć szesnastowieczną editio princeps Fortuny, pisząc nie tylko o miejscu i czasie jej powstania, ale także o wyglądzie pierwodruku.

ku Łazarza z 1561 roku (Pedro Ruis de Moros, Carmen funebre in obitu Ioannis Tarnovii, egz. Biblioteki Jagiellońskiej, sygn. Cim 4429) na k. B3v. jest Tymoteus z Fortuny. Klocek, z którego odbito wizerunek, był mniej uszkodzony niż wtedy, gdy Łazarz tłoczył książkę Stanisława z Bochnie. Druga data (1577) to rok śmierci Andrysowica.

${ }_{13}$ Dedykacja ta powiększa zasób znanych nam dotychczas piętnastu dedykacji podpisanych przez Wietora. Por. A. Mańkowska, A. Kawecka-Gryczowa, Wietor Hieronim, w: Drukarze dawnej Polski od XV do XVIII wieku, t. 1: Małopolska, cz. 1: Wiek XV-XVI, red. A. Kawecka-Gryczowa, Wrocław 1983, s. 350-352.

${ }^{14}$ Por. H. Kapełuś, Stanisław z Bochnie, kleryka królewski (Studia Staropolskie, t. 13), Wrocław 1964; Stanisław z Bochnie Gąsiorek, Fortuna abo Szczęście, wyd. J. Kiliańczyk-Zięba, Kraków 2015 oraz starsza literatura przedmiotu wykazana we wstępie do edycji Fortuny. 
Było to przedstawienie propozycji metody, która może pomóc „odzyskiwać” dla naszej refleksji badawczej książki fizycznie nieistniejące, ale uchwytne dzięki „późnym wnukom”15. Poniżej przywołane zostaną wyniki tego dawniejszego dowodzenia w zestawieniu z materiałem nowym - szesnastowieczną edycją Fortuny, którą znalazłam w bibliotece w Monachium.

Fortuna to kolekcja wierszowanych wróżb, wydawana jako bogato ilustrowany drzeworytami tom ${ }^{16}$. Czytając Fortune (czy raczej przepowiadając z niej przyszłość), należało wybrać jedno z 21 pytań zaproponowanych na początku tomu (Czy szybko wyjdę za mąż? Czy odnajdzie się rzecz zgubiona? Czy będę bogaty? Czy powinienem zostać księdzem? Czy szukać nowej pracy?). Żeby dostać odpowiedź, trzeba było rzucić dwiema kostkami, a potem dać się poprowadzić przez kolejne etapy gry, aż do wskazanej przez los przepowiedni. Na przykład pytający o to, czy warto się ożenić, szukał wyniku swego rzutu kośćmi na „kole Fortuny”, w którego centrum odbito wronę. Wróżbie patronowali Alcestis i Admetus. Jeśli pytający wyrzucił na przykład $3+3$, otrzymywał polecenie: „idź do borsuka, miasta Szamotuły". Oznaczało to, że w drugiej serii diagramów należało odnaleźć ten z borsukiem, a na nim komórkę z nazwą miasta. Obok znajdowała się wskazówka „Sybilla 11, wiersz 17”. Gracz przewracał więc strony książki i czytał siedemnastą wróżbę Sybilli Kumejskiej:

Radząć obie dryje sprawiedliwie:

Pojmi żonę wnet po żniwie,

Bo ondzie zimie za mrozu,

Cieplej dwiema społem w łożu ${ }^{17}$.

15 J. Kiliańczyk-Zięba, In Search of Lost Fortuna. Reconstructing the Publishing History of the Polish Book of Fortune-Telling, w: Lost Books..., s. 120-143.

16 Zob. Stanisław z Bochnie Gąsiorek, Fortuna... W edycji zreprodukowano w niewielkim pomniejszeniu egzemplarz z 1665 roku z Biblioteki Premonstratensów na Strahowie (Strahovská Knihovna v Klášteře Premonstrátů) w Pradze. Przez przeoczenie nie powielono dwóch całostronicowych drzeworytów otwierających książkę Gąsiorka.

17 Ibidem, s. 261. 
Sybille dawały grającym odpowiedzi żartobliwe, dwuznaczne albo nawet obraźliwe. Ekscytacja towarzysząca próbom odgadnięcia przyszłości mieszała się z wybuchami śmiechu, a „radzić się"18 Fortuny można było w samotności albo w gronie przyjaciół.

Na unikatowy, zdefektowany egzemplarz Fortuny, wydrukowany w XVII wieku, a przechowywany w Bibliotece Narodowej, pierwsza zwróciła uwagę w latach 60. ubiegłego stulecia Helena Kapełuś, pracując nad monografią Stanisława z Bochnie Gąsiorka (nazywanego Kleryką, kapelana Zygmunta Starego, wuja Łukasza Górnickiego, poety zmarłego w 1562 lub w 1563 roku). Kapełuś zidentyfikowała kolekcję wróżb jako jego dzieło. Przyglądając się samemu drukowi, badaczka pisała:

[...] użyte w Fortunie elementy drukarskie [...] pochodzą z różnych i to bardzo od siebie odległych czasów, nawarstwiając się niby pokłady geologiczne. Najmłodsze z nich wywodzą się z wieku XVII, najstarsze zaś datą swego powstania odbiegają wstecz o lat niemal sto [...]. Przegląd tej części materiału ilustracyjnego, który wywodzi się z w. XVI, dostarczyć może informacji o pierwodruku: data z koła z gąsiorkiem (k. Ala, s. 7) wskazuje na rok 1531 jako czas powstania drzeworytu. Ta sama data powtarza się jeszcze na innym drzeworycie, przedstawiającym postać Sybilli (k. 11, s. 29, 37) ${ }^{19}$.

Obserwacje te prowadziły Kapełuś do wniosku, że

Fortuna Stanisława Kleryki została wydana po raz pierwszy w r. 1531. Za datę pierwodruku przyjąć należy datę z drzeworytów, nie może być tu mowy o zastosowaniu do edycji Fortuny drzeworytu starszego, sporządzonego uprzednio dla innych celów, oznaczone bowiem tym rokiem pierwsze koło nie nadawało się do reprodukowania w druku o innym charakterze $[\ldots]^{20}$.

${ }_{18}$ J. Sokolski, „Fortuna radzi...”, czyli uwagi o dwóch fraszkach Jana Kochanowskiego, „Pamiętnik Literacki” 86 (1995), s. 133-137; J. Sokolski, „Sybilla prorokuje...” O fraszce Do Stanisława (I, 63) Jana Kochanowskiego, „Pamiętnik Literacki” 90 (1999), s. 149-152; J. Sokolski, Bogini, pojęcie, demon. Fortuna $w$ dziełach autorów staropolskich, Wrocław 1996, s. 97 i nn.

${ }_{19}$ H. Kapełuś, Stanisław..., s. 77.

${ }^{20}$ Ibidem, s. 78. 
Wyobrażenie gąsiorka, jak i inne wizerunki ptaków i zwierząt patronujących wróżeniu nie były integralnymi częściami kół fortuny i mogły być używane także w odmiennych kontekstach ${ }^{21}$. Jednak rozumowanie Heleny Kapełuś i tak było słuszne, bo zarówno oba datowane drzeworyty - rycina $\mathrm{z}$ gąsiorkiem i Sybilla, jak i jednolite stylistycznie zespoły, do których ilustracje te należą, wycięte zostały specjalnie dla Fortuny. Świadczy o tym ich ścisły związek z treścią i strukturą pracy Stanisława z Bochnie. Ostrożniej byłoby jednak przyjąć, iż editio princeps Fortuny ukazała się albo w 1531 roku, albo niewiele później, i pisać o wydaniu z około 1531 roku.

Kilka lat temu odnalazłam nową kopię Fortuny abo Szczęścia - nieznany wcześniej ani polskim historykom literatury, ani bibliografom unikatowy egzemplarz późniejszego wydania niż to, które znajduje się w Bibliotece Narodowej w Warszawie. Książka w zbiorach Biblioteki Premonstratensów na Strahowie w Pradze okazała się kopią tym cenniejszą, że kompletną, ze stroną tytułową identyfikującą edycję jako publikację z 1665 roku wytoczoną w „Drukarni u Dziedziców Stanisława Bertutowica”. Również i tę Fortunę wyprodukowano, używając materiału typograficznego „z różnych i to bardzo od siebie odległych czasów”, nawarstwiającego się „niby pokłady geologiczne”. Oglądając egzemplarze siedemnastowiecznych edycji Fortuny, można było łatwo dostrzec dwie rzeczy: po pierwsze, że materiał użyty do ich zilustrowania pochodzi w swojej najstarszej części z pierwszych dziesięcioleci XVI wieku i da się go odnaleźć w książkach z oficyny Hieronima Wietora. Po drugie - że obie edycje siedemnastowieczne są do siebie uderzająco podobne.

Rozwińmy najpierw pierwszą obserwację: do wytłoczenia obu wydań z XVII stulecia wykorzystano klocki drzeworytnicze powstałe w latach 20. i 30. XVI wieku. Były wśród nich deski, które wycięto z myślą o „książce losów”: diagramy z wynikami rzutów kośćmi,

${ }^{21} \mathrm{Na}$ przykład żuraw patronujący pytaniu, czy warto zostać kupcem, widnieje także na stronie tytułowej Disciplina puerorum, Kraków: Hieronim Wietor [po 1541], egz. Biblioteki Kórnickiej PAN, sygn. Cim O.335. 
wizerunki ptaków (w tym gąsiorka $z$ datą 1531), przedstawienia zwierząt, wizerunki Sybilli i wyobrażenia figuralne otwierające tom ${ }^{22}$. Drukarze siedemnastowiecznych edycji sięgnęli też po klocki, które pewnie nie były opracowane z myślą o książce Kleryki: na przykład po „półfigury w kielichach kwietnych”, czyli serię przedstawień o gotyckich jeszcze cechach stylowych, i po inne ryciny figuralne, które w Fortunie wykorzystano jako portrety mitycznych postaci (il. 1, 2).

Wiele z tych drzeworytów pojawia się już w publikacjach Wietora, co musiało nasunąć myśl, że pierwodruk kolekcji Stanisława z Bochnie ukazał się w oficynie Hieronima ${ }^{23}$. Była to atrybucja tym bardziej prawdopodobna, że Wietor był jednym z pierwszych działających w Królestwie drukarzy, którzy dostarczali lektury pragnącym czytać po polsku. Istotne było również i to, że siedemnastowieczne wydania Fortuny, których egzemplarze znamy dzisiaj, wyprodukowane zostały przez drukarzy, których warsztaty wchłonęły zasoby dawnej oficyny Hieronima. Stanisław Lenczewski Bertutowic, którego „dziedzice” odbili edycję z 1665 roku (unikat na Strahowie w Pradze), kupił wyposażenie drukarni Waleriana Piątkowskiego. Piątkowski (który wydrukował

22 Zarówno wizerunki Sybilli, jak i przedstawienia Fortuny abo Szczęścia oraz Szczęścia abo Nieszczęścia należą do grafik włosko-antykizujących. O pojawieniu się ich w krakowskich drukach z początku lat 30. XVI wieku pisała niegdyś E. Chojecka (O tematach i formach antykizujących w grafice polskiej XVI wieku, „Biuletyn Historii Sztuki” 32 (1970), nr 1, s. 25). Chojecka nie znała drzeworytów z książki Kleryki, pisała jednak o rycinie będącej późną kopią Fortuny-Occasio, którą odbijano na odwrocie karty tytułowej Fortuny albo Szczęścia Seweryna Bączalskiego (najstarsze znane wydania pochodzą z lat 1644-1646). W drukach Wietora drzeworyty o charakterze renesansowym odbijano z importowanych desek i z klocków wykonywanych przez miejscowych artystów „w procesie asymilacji dzieł grafiki obcej na gruncie polskim”. Cyt. za: E. Chojecka, Związki artystyczne polskiego drzeworytu renesansowego z grafika europejska. Kryspin $i$ Wendel Szarffenbergowie (Acta Universitatis Wratislaviensis, no. 364, Bibliotekoznawstwo, t. 7), Wrocław 1978, s. 181-182.

23 Por. Historyja o świętym Jozefie, Kraków: Hieronim Wietor, 1530 (egz. Biblioteki Kórnickiej PAN, sygn. Cim.O.300); P. Ciświcki, Adolescentis epistola, Kraków: Hieronim Wietor, 1535 (egz. Biblioteki Kórnickiej PAN, sygn. Cim.O.81); A. Guarna, Grammaticae opus, Kraków: Hieronim Wietor, 1534 (egz. Biblioteki Zakładu Narodowego im. Ossolińskich we Wrocławiu, sygn. XVI.O.471). 


\section{N E S T O R}

46 4 3 (1)
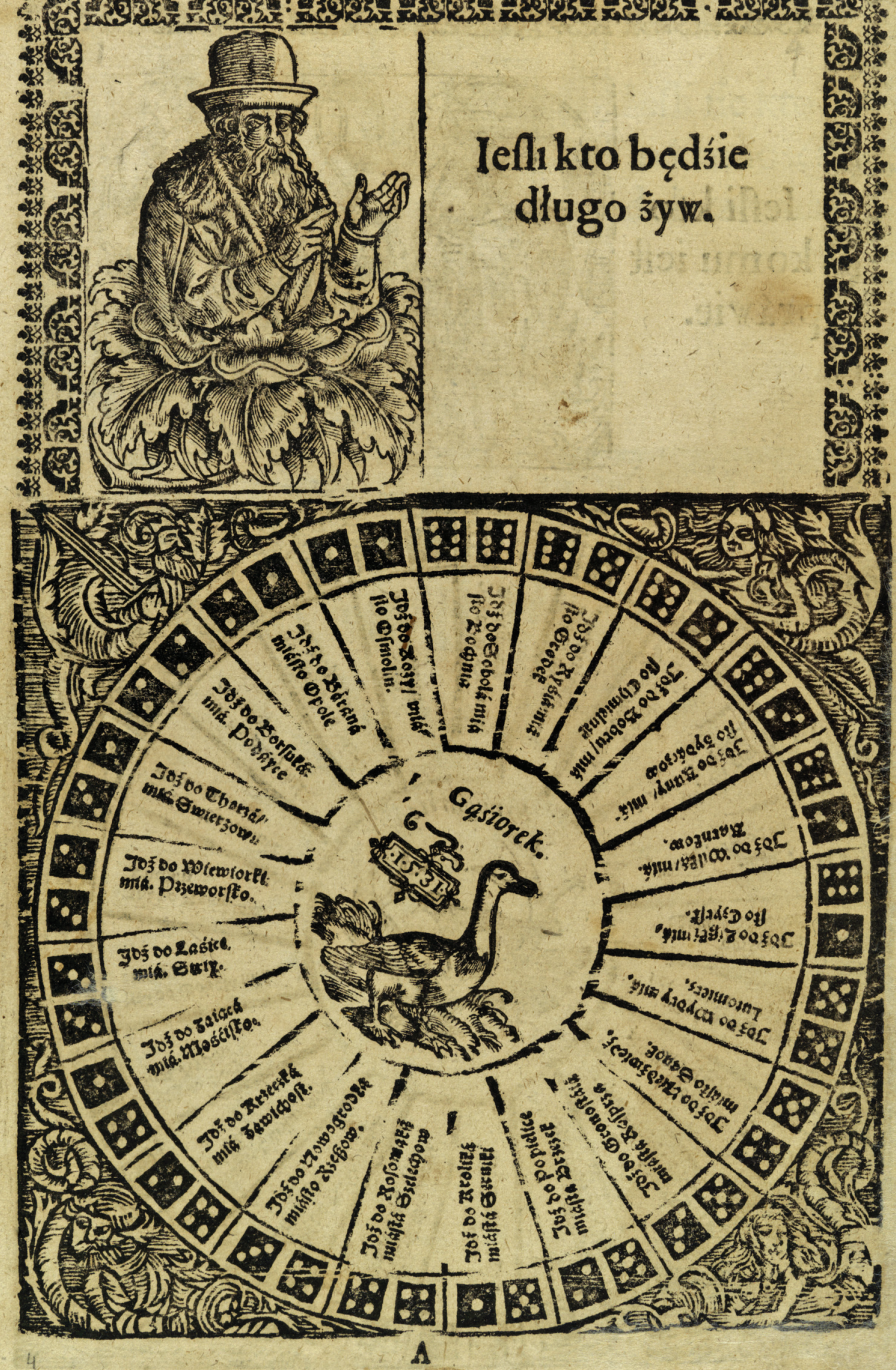

Il. 1. Stanisław z Bochnie, Fortuna abo Szczęście, [Kraków: Walerian Piątkowski, ca 1649] (Biblioteka Narodowa, Warszawa, XVII.4.3504) 


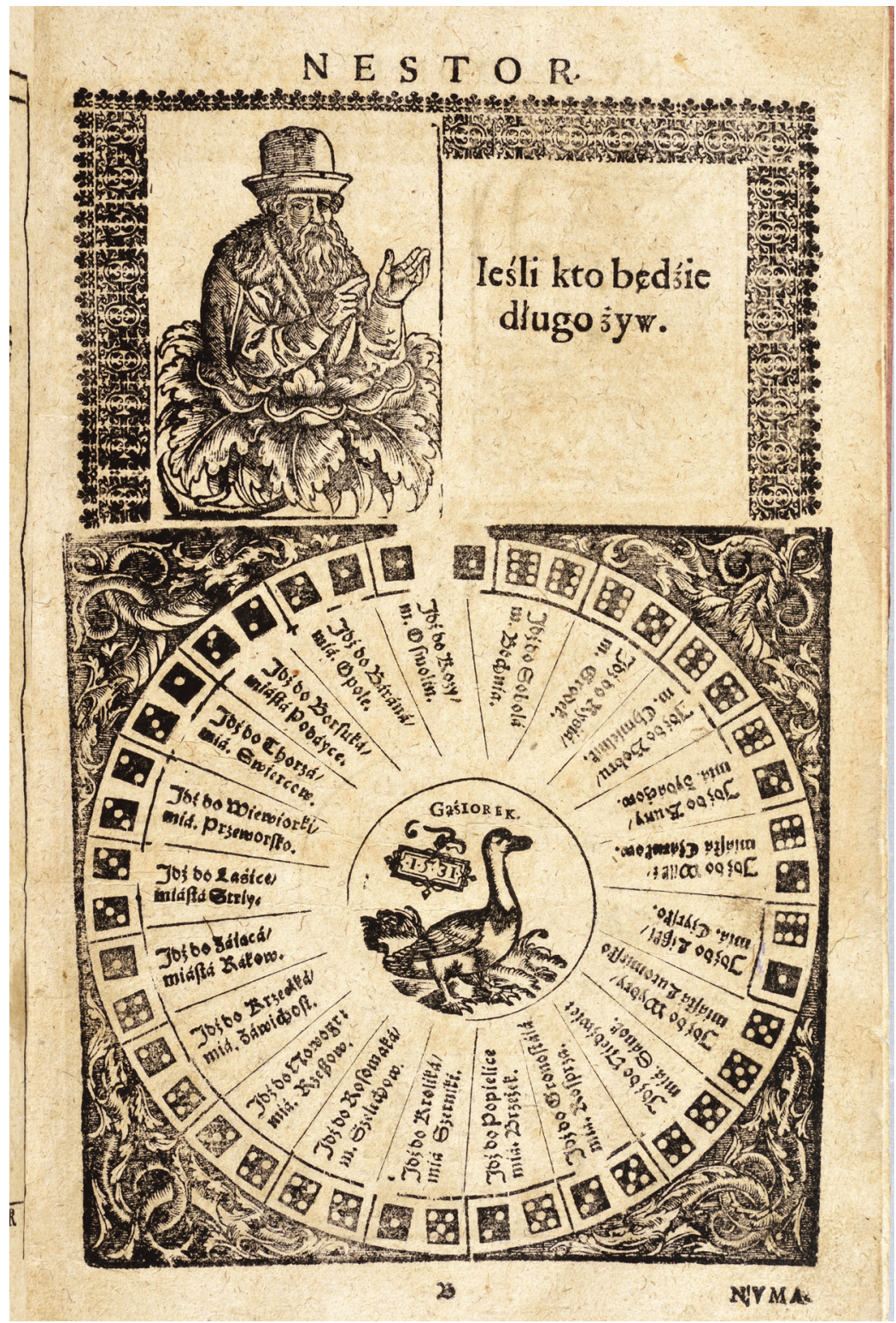

Il. 2. Stanisław z Bochnie, Fortuna abo Szczęście, Kraków: Dziedzice Stanisława Bertutowica, 1665 (Strahovská Knihovna v Klášteře Premonstrátů, Praga, AG XII 25) 
kopię Fortuny przechowywaną w Bibliotece Narodowej w Warszawie) był zięciem Macieja Jędrzejowczyka i po śmierci teścia przejął jego krakowski warsztat. Jędrzejowczyk zaś, zakładając swoją typografię, kupił od synów Jana Januszowskiego wyposażenie Oficyny Łazarzowej. A Januszowski odziedziczył drukarnię in platea Columbarum po ojcu Łazarzu Andrysowicu i matce Barbarze Wietorowej, niegdyś żonie Hieronima.

Oba egzemplarze z XVII wieku - zdefektowana kopia z Biblioteki Narodowej i kompletny unikat ze Strahowa - nie tylko wskazywały czas powstania editio princeps Fortuny (około 1531) oraz jej drukarza i miejsce wytłoczenia (Hieronim Wietor, Kraków). Nasuwały także myśl, że podobieństwo ich kształtu edytorskiego nie jest przypadkowe, ale odziedziczone zostało po wcześniejszych wydaniach tomu, które z kolei naśladować musiały pierwodruk z początku lat 30. XVI wieku. Oba siedemnastowieczne egzemplarze Fortuny mają bowiem identyczną wieloelementową strukturę. Tomy otwierają całostronicowe drzeworyty, najpierw Fortuna-Occasio, potem wyrzezane według średniowiecznych modeli koło Fortuny. Dalej znajdujemy tworzące ramę wydawniczą wierszyki, instrukcję dla graczy, listę pytań, które zadać można było Sybillom (il. 3, 4). Bogato ilustrowaną część obu tomów tworzy zespół stron, na których rzucano kośćmi, oraz seria kół ze zwierzętami. Dalej odbito wierszowane wróżby. Kształt wizualny obu edycji również jest zbliżony, niemal identyczny. Oba wydania zaprojektowane były w formacie folio. Pierwsza część tomu zdominowana została przez ilustracje: u góry każdej ze stron odbito pytanie do „wyroczni”, imię mitycznej postaci, z której losami można było skojarzyć dany życiowy dylemat, i jej umowny prostokątny wizerunek (zajmujący mniej więcej połowę szerokości składu). Poniżej wytłoczono koła w ornamentalnym obramieniu, a w centrum każdego z nich znalazł się ptak patronujący wróżeniu. Następna część tomu przynosiła drugi zestaw kół. Żywą paginę stanowiły tutaj nazwy zwierząt odbitych w centrum diagramów. Także layout finalnej części księgi losów w obu edycjach jest bardzo podobny. Oracula wydrukowano w dwunastu rozdziałach, których nagłówki akcentują drzeworytowe wizerunki Sybilli, wyśrodkowane, umieszczone nad kolumną wierszowanego tekstu złożonego szwabachą (il. 5, 6). Na 
poszczególnych stronach egzemplarzy obu wydań umieszczono tyle samo czterowersowych wróżb, numerując je i oddzielając od siebie liniami. Jeśli opracowanie graficzne obu siedemnastowiecznych edycji różni się, to tylko w szczegółach. Na przykład w książce Bertutowiców na stronach $z$ Sybillami składacz zastosował rozwiązanie nieco bardziej dekoracyjne niż to znane z wydania Piątkowskiego: zamiast prostych, surowych linii wizerunki wieszczek okalają w wydaniu z 1665 roku ornamentalne listwy złożone z drobnych elementów.

Nie ma wątpliwości, że albo edycję z 1665 roku złożono, spoglądając na publikację Piątkowskiego, albo - obie książki naśladują kształt edytorski starszego jeszcze wydania, $\mathrm{w}$ którym z kolei znalazła odzwierciedlenie architektura wcześniejszej edycji, może nawet editio princeps. Spoglądając na książki z XVII wieku, można było także wyrazić przypuszczenie, że szesnastowieczne wydania Fortuny, w tym zapewne i pierwodruk, były w dużej części ilustrowane tymi samymi drzeworytami, co edycje z XVII wieku. Nawet jeśli niektóre z pierwotnie używanych klocków zastąpione zostały innymi deskami (nowszymi lub przez Wietora używanymi w odmiennych kontekstach), przynajmniej te, które wycięto z myślą o Fortunie, odbijano w XVII wieku w tych samych miejscach i funkcjach, co tłocząc wczesne edycje zbioru, w tym także - editio princeps.

Słuszność tego rodzaju rozumowania potwierdzały dodatkowe poszlaki. Po pierwsze, konserwatyzm edycji kolekcji wróżb podobnych do Fortuny, które tłoczono na Zachodzie Europy. Najstarszy drukowany zbiór tego typu, Il libro delle sorti autorstwa Lorenza Spirita, ukazał się w 1482 roku w Perugii. Kiedy książkę tę w jej włoskiej wersji przedrukowywano (a okazała się bestsellerem), do produkcji większości wznowień albo używano stale tych samych klocków drzeworytniczych, albo desek nowych, ale ciętych na wzór starych ilustracji. Składając kolejne strony, naśladowano rozwiązania projektowe zaproponowane w piętnastowiecznym wydaniu Il libro ${ }^{24}$. Co więcej,

${ }_{24}$ T. de Marinis, Le illustrazioni per il libro de le sorte di Lorenzo Spirito, w: idem, Appunti e ricerche bibliografiche, Milano 1940, s. 69-83. 


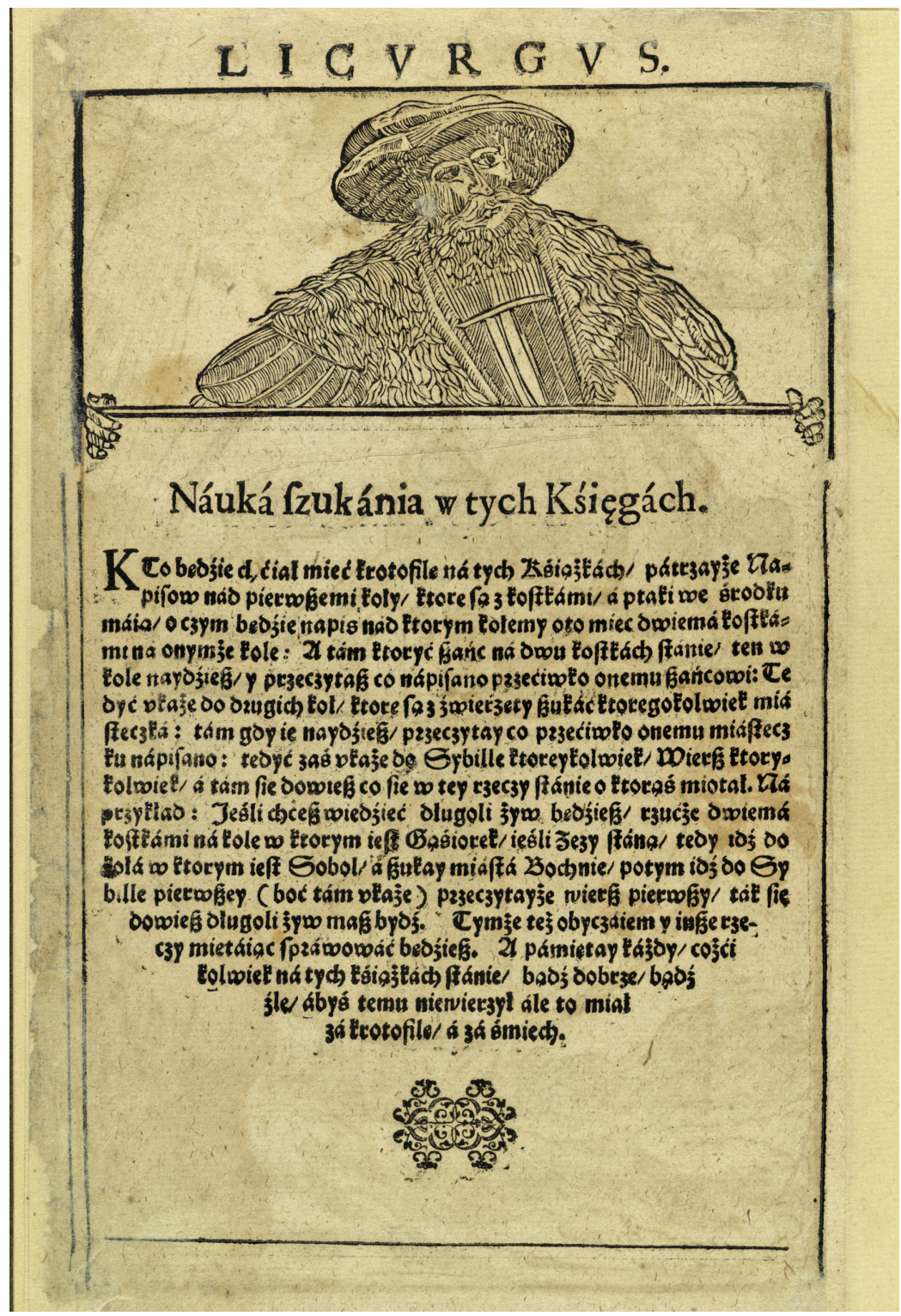

Il. 3. Stanisław z Bochnie, Fortuna abo Szczęście, [Kraków: Walerian Piątkowski, ca 1649] (Biblioteka Narodowa, Warszawa, XVII.4.3504) 


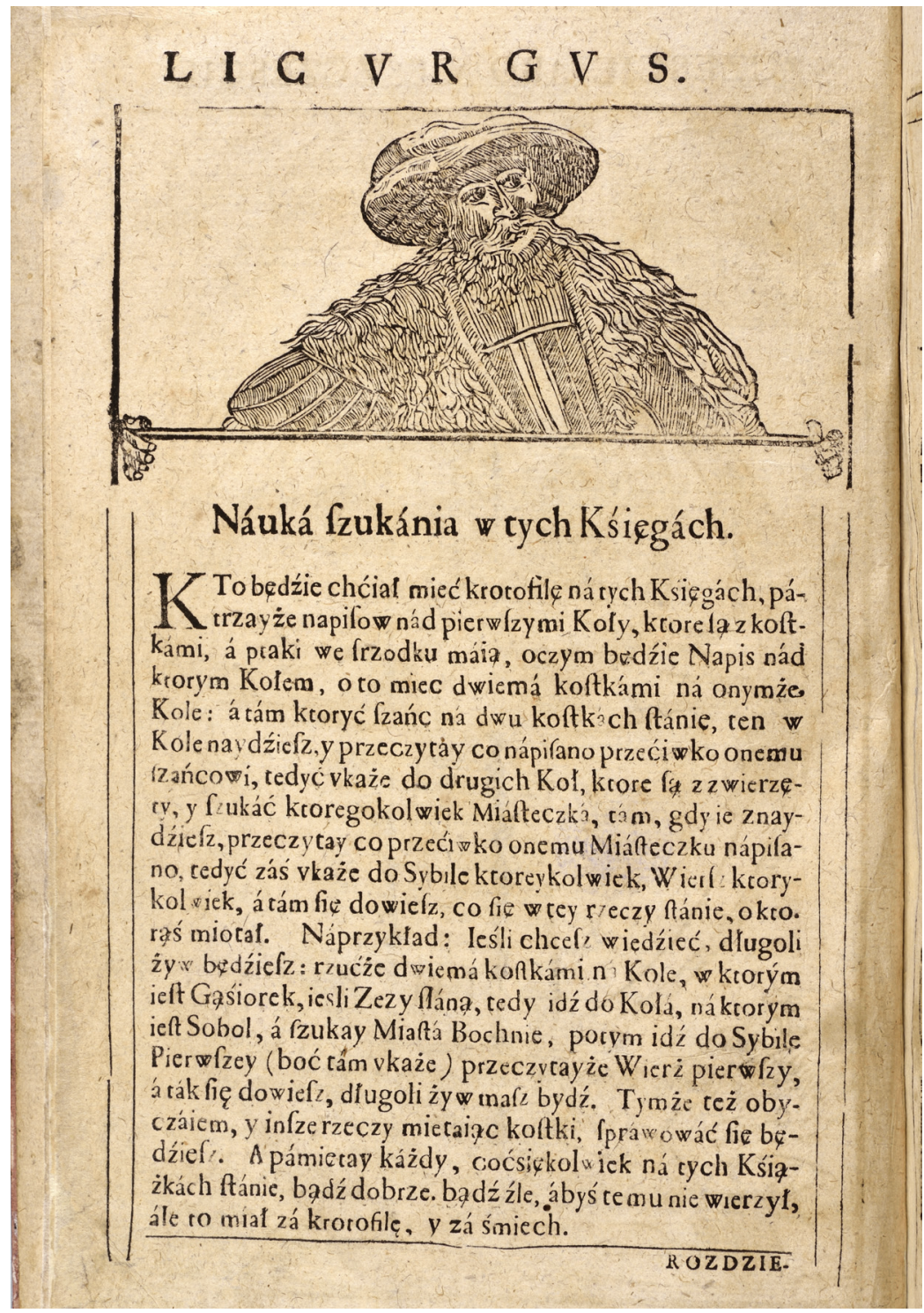

Il. 4. Stanisław z Bochnie, Fortuna abo Szczesście, Kraków: Dziedzice Stanisława Bertutowica, 1665 (Strahovská Knihovna v Klášteře Premonstrátů, Praga, AG XII 25) 


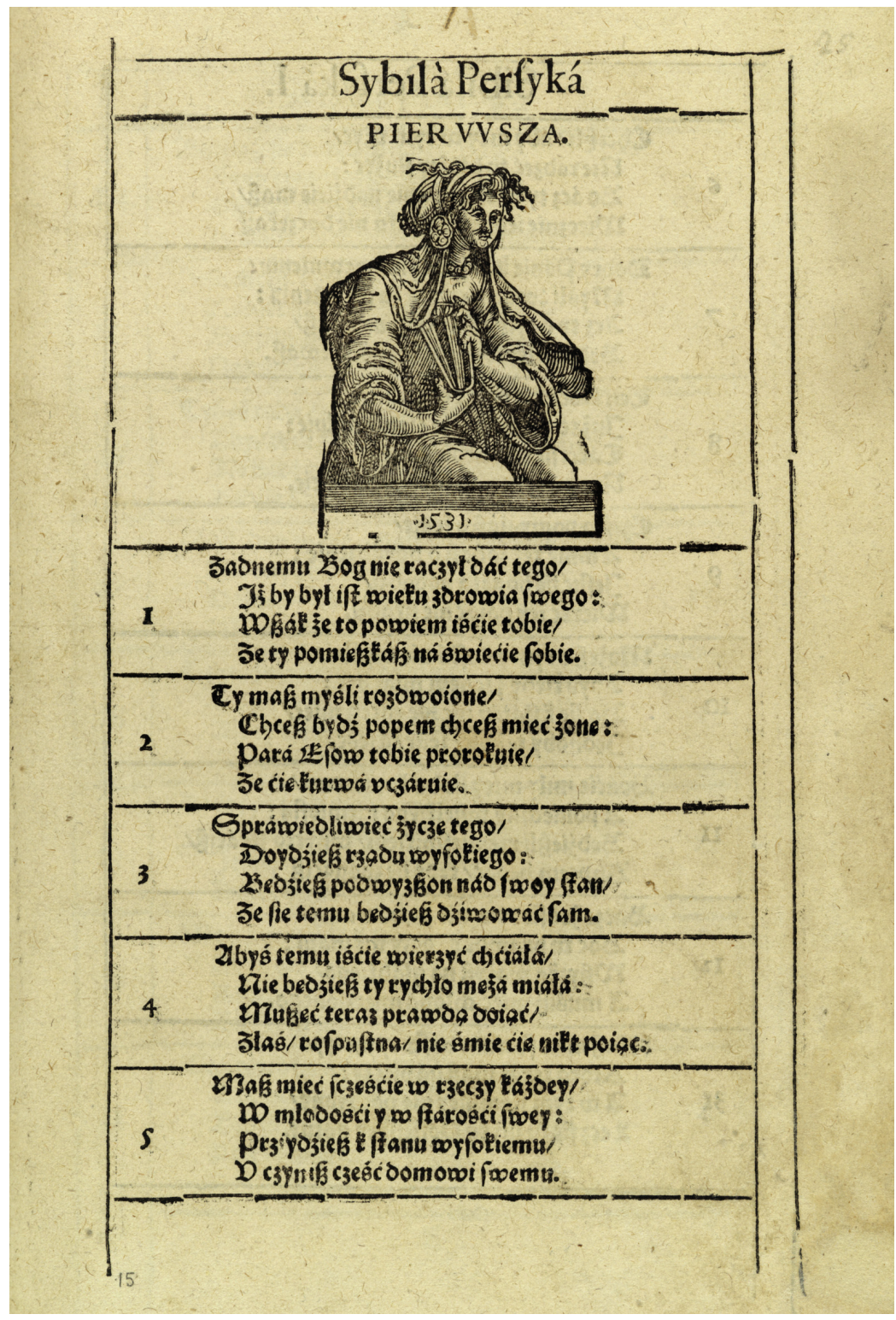

Il. 5. Stanisław z Bochnie, Fortuna abo Szczęście, [Kraków: Walerian Piątkowski, ca 1649] (Biblioteka Narodowa, Warszawa, XVII.4.3504) 


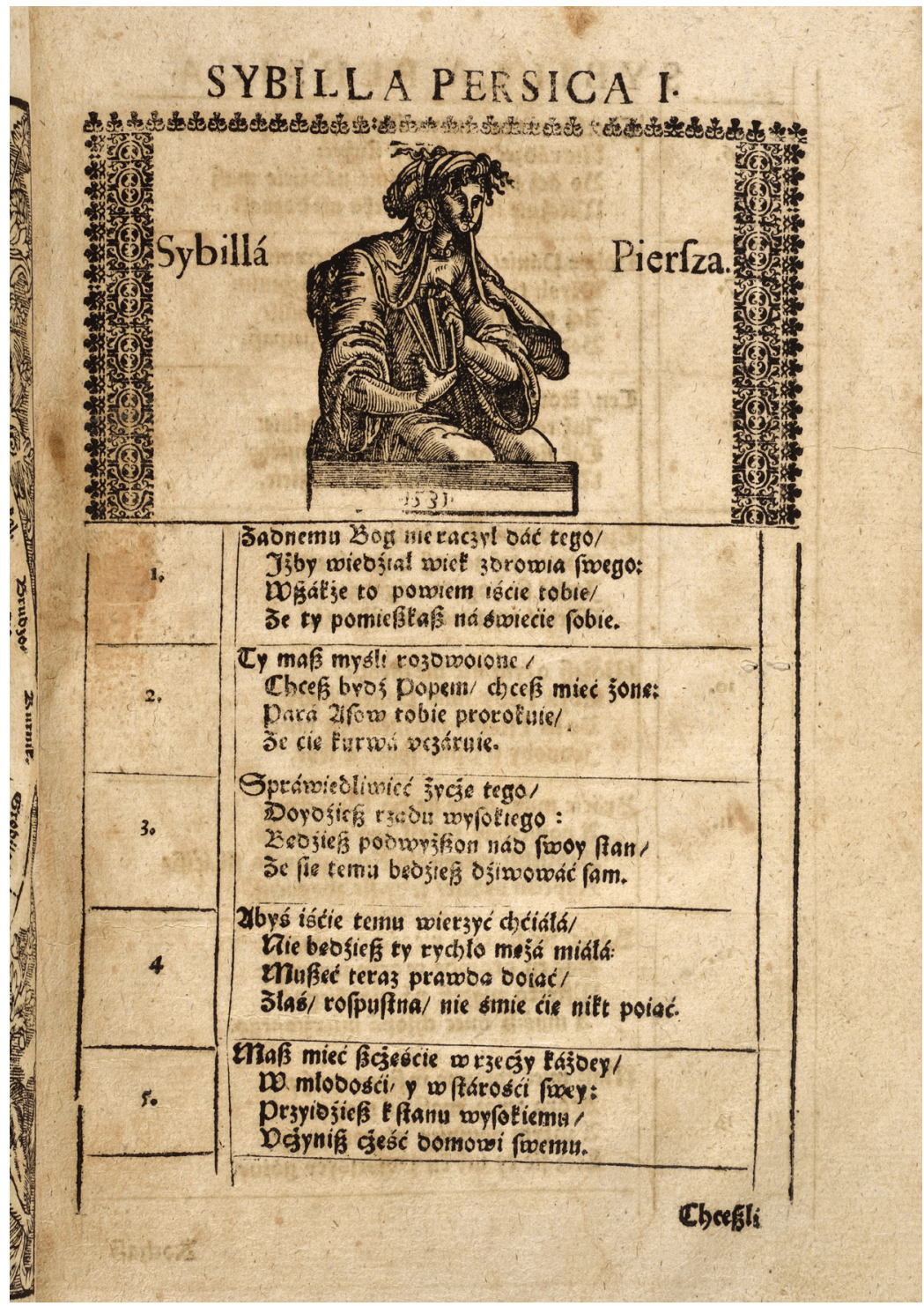

Il. 6. Stanisław z Bochnie, Fortuna abo Szczęście, Kraków: Dziedzice Stanisława Bertutowica, 1665 (Strahovská Knihovna v Klášteře Premonstrátů, Praga, AG XII 25) 
drukarze przekładów pracy Spirito na inne języki narodowe, na przykład francuski, także naśladowali sprawdzone już wzorce. Mimo że poświadczone w istniejących egzemplarzach edycje różnią się między sobą, wszystkie mają podobny layout, którego źródło łatwo wskazać w inkunabułowych włoskich wydaniach Il libro.

Myśl, że siedemnastowieczne Fortuny były wydawniczymi skamielinami, nasuwały także edycje węgierskiego przekładu kolekcji oraz wydania przeróbki Fortuny (pióra Jana Gawińskiego). Węgierska Fortuna zachowała się w postaci dwóch pochodzących z odrębnych edycji egzemplarzy, które wydrukowano na przełomie XVI i XVII wieku $^{25}$. Egzemplarz znany pod nazwą Fortuna pochodzi z edycji wcześniejszej i ukazał się drukiem w latach 1599-1610 w Kluż-Napoka (wówczas Kolozsvár) $^{26}$. Kopia katalogowana jako Sybillák jövendölése (Proroctwa Sybilli) została wytłoczona około 1616 roku w Bardiowie (wtedy Bártfa) ${ }^{27}$. Kształt edytorski ksiąg losów w obu wersjach językowych - po polsku i po węgiersku - jest bardzo podobny. Identyczna jest struktura kolekcji: 21 pytań, serie kół oznaczonych zwierzętami, taki sam układ odpowiedzi 12 Sybilli. Także layout węgierskich edycji zdradza ich zależność od krakowskiego pierwowzoru, mimo że i Fortuna, i Sybillák jövendölése wytłoczone zostały w formacie quarto.

${ }^{25}$ Informacje o węgierskim przekładzie Fortuny przytaczam za: H. Kapełuś, J. Ślaski, Polski druk popularny na Wegrzech. Z dziejów „Fortuny”, „Rocznik Biblioteki Narodowej” 2 (1966), s. 297-317. Zob. także: G. Borsa, Hol és mikor nyomták az eddig ismert két legrégibb magyar sorsvetö könyvet?, w: idem, Könyvtörténeti írások I. A hazai nyomdászat 15-17 század, Budapest 1996, s. 295-300; G. Borsa, A „Fortuna" sorsvetökönyv eredete és utólete, w: idem, Könyvtörténeti írások..., s. 301-306. Oba artykuły ukazały się wcześniej w „Magyar Könyvszemle”, odpowiednio w 1964 i 1966 roku. Zob. także: G. Borsa, Alte siebenbürgische Drucke (16. Jahrhundert), Köln 1996, Nr. 361.

${ }^{26}$ Dziś Kluż-Napoka (rum. Cluj-Napoca) w Rumunii. Fragment w Országos Széchényi Könyvtár, Budapeszt (RMK I. 361b). Wydawca Jakub Klos wspominał w przedmowie, że przed kilkoma laty jako pierwszy drukował zbiór po węgiersku, a teraz oddaje do rąk czytelników poprawioną wersję tekstu.

${ }^{27}$ Dziś Bardiów (słow. Bardejov) na Słowacji. Fragment w Országos Széchényi Könyvtár, Budapeszt (RMK I. 350). Cyfrowa reprodukcja: http://oszkdk.oszk.hu/ storage/00/00/67/64/dd/1/RMK_I_0350.pdf (dostęp: 17.11.2019). 
Skopiowano między innymi całostronicowe ryciny przedstawiające Fortunę i koło Fortuny oraz część wizerunków Sybilli, naśladowano medaliony z ptakami i zwierzętami, a rozkład materiału typograficznego i ilustracji na stronach, na których pomieszczono przepowiednie, wyraźnie wzorowany był na krakowskim druku. Zarówno polskie siedemnastowieczne edycje, jak i węgierskie książki z przełomu stuleci musiały mieć wspólnego przodka. Być może dalekiego, bo nie można - rzecz jasna - sądzić, że i Piątkowski, i dziedzice Bertutowica, i typografowie z dzisiejszego Bardiowa i z Kluż-Napoka opracowali swoje wydania Fortuny na podstawie egzemplarza tej samej edycji. Jednak niezależnie od tego, które konkretnie wydania Fortuny służyły im jako wzorzec, kształt edytorski węgierskich publikacji jest niewątpliwie więcej niż tylko echem projektu zaproponowanego niegdyś dla Klerykowej księgi w warsztacie Wietora.

Ów konserwatyzm edytorski znalazł odzwierciedlenie także w edycjach przeróbki Gąsiorkowego sortilegium - Fortunie abo szczęściu Jana Gawińskiego ${ }^{28}$. Przygotowania do tej publikacji rozpoczęto być może już pod koniec lat 70 . XVII wieku (jeden z drzeworytów oznaczony jest datą 1678). W XIX wieku Żegota Pauli opisał jeszcze „Fortunę abo szczęście przez Jana Gawińskiego wierszem polerowniejszym z starego udarowaną ${ }^{29} \mathrm{w}$ wydaniu z 1690 roku z Drukarni Akademii w Krakowie. Żaden egzemplarz siedemnastowiecznej publikacji nie jest dziś znany, ale wnioskowanie o jej wyglądzie umożliwia zachowana kopia późniejszej edycji, wytłoczonej w 1744 roku przez Michała Dyjaszewskiego w Krakowie ${ }^{30}$.

Kiedy Gawiński adaptował archaiczny tekst Stanisława z Bochnie, drzeworytnik Mikołaj Bereszniewicz pracował nad ilustracjami

${ }^{28}$ D. Chemperek, Poezja Jana Gawińskiego i kultura literacka drugiej połowy XVII wieku, Lublin 2005, s. 323-336.

${ }^{29}$ Ż. Pauli, Wiadomości o życiu i pismach Jana z Wielomowic Gawińskiego, w: Poezje Jana $z$ Wielomowic Gawińskiego, wyd. idem, Lwów 1843, s. [19-20].

${ }^{30}$ Znane są dwa egzemplarze Fortuny w przeróbce Gawińskiego: 1) w Bibliotece Narodowej w Warszawie, sygn. XVIII.3.5734, bez karty tyt.; 2) w Bibliotece Zakładu Narodowego im. Ossolińskich we Wrocławiu, sygn. XVIII. 15649-IV. 
do bardziej odpowiadającej współczesnemu smakowi Fortuny. Deski szesnastowieczne, pochodzące $\mathrm{z}$ warsztatu Wietora, wtedy już w większości nie istniały. Zarządca oficyny Bertutowiców, Jan Kubiński, zostawił je w piwnicy domu przy ulicy św. Jana, gdy opuszczał Kraków w 1669 roku $^{31}$. Kiedy w 1681 roku inwentaryzowano jego porzucone ruchomości, znaleziono „relikwije drukarskich rupieci, co to wszystko wniwecz pogniło i popsowało się"32. Bereszniewicz ciął więc nowe klocki. Spoglądał jednak na stare wydanie Fortu$n y$ : powielił rozwiązania ikonograficzne i formalne, upraszczając je i prymitywizując; powtórzył nawet zabieg datowania ilustracji (il. 7). Zaś drukarz „nowej Fortuny”, dla którego Bereszniewicz pracował, użył owych drzeworytów do produkcji książki, która stanowiła adaptację wizualnego ukształtowania szesnastowiecznego zbioru. Drukując pracę Gawińskiego, nie zdecydował się na przykład zrezygnować ze szwabachy jako pisma tekstowego, mimo że w XVII wieku kroje antykwowe stopniowo upowszechniały się również w książkach w języku polskim. Nie zarzucił nawet ramek, w publikacji osiemnastowiecznej robiących wrażenie reliktu obyczaju dawno przebrzmiałego (il. 8).

Oczywiście autorzy kształtu edytorskiego „nowej Fortuny”, powielając dawne wzorce, dokonywali modyfikacji zgodnych z możliwościami swojego warsztatu, gustem czy talentem. Nie widzieli jednak potrzeby, by czytającej publiczności zaproponować świeże rozwiązania. Z jednej strony dowodzi to tradycjonalistycznego nastawienia miejscowego środowiska rytowniczo-drukarskiego, które było mało ekspansywne i nowatorskie. $Z$ drugiej strony wytrwałe powielanie wzorca świadczy o jego atrakcyjności. Skoro Fortune postrzegano jako spójny i funkcjonalny projekt wydawniczy nawet 200 lat po tym, jak pierwszy raz trafiła w ręce czytelników, to można

${ }^{31}$ J. Kracik, Jan Kubiński - nieznany typograf krakowski XVII wieku?, „Biuletyn Biblioteki Jagiellońskiej" 39 (1989), s. 14 (oryginał dokumentu w Archiwum Narodowym w Krakowie, Acta inventariorum 256, s. 1036-1044).

${ }^{32}$ Ibidem, s. 16. 
sądzić, że kształt edytorski, który nadano kolekcji w oficynie Hieronima Wietora, $\mathrm{z}$ większą jeszcze siłą musiał narzucać się drukarzom tłoczącym jej pierwsze wznowienia. Projektując swoje edycje, powtarzali oni strukturę i ukształtowanie wizualne pierwodruku z 1532 roku. Drukarze pracujący w XVII i XVIII wieku, nawet jeśli nie mieli w rękach editio princeps Fortuny, ale jej późniejsze wydania, i tak obcowali za ich pośrednictwem ze starszą tradycją. Struktura i wizualne ukształtowanie ich edycji było nie tylko echem, ale naśladownictwem kształtu edytorskiego pierwodruku.

Najlepszym testem, sprawdzającym słuszność tego rodzaju rozumowania, byłoby zestawienie siedemnastowiecznych wydań Fortuny i edycji z XVIII wieku z pierwodrukiem kolekcji - fizycznie, faktycznie zachowanym. Nadzieja na taką konfrontację pojawiła się, kiedy w katalogu Bayerische Staatsbibliothek w Monachium znalazłam informację o przechowywanej tam Fortunie, opisanej jako anonim typograficzny z 1532 roku $^{33}$. Książka ta rzeczywiście okazała się szesnastowiecznym wydaniem kolekcji Stanisława z Bochnie. Wyszła jednak nie z warsztatu Wietora, ale drukarza, który przejął jego zasoby. Świadczy o tym adres wydawniczy odbity pod listą pytań do losu: „Łazarz Andrysowic drukował” (il. 9). Jednak dzięki monachijskiemu znalezisku potwierdziło się przypuszczenie Heleny Kapełuś, że Wietor tłoczył Fortunę wcześniej „około 1531 roku” - Łazarz Andrysowic bowiem (jak już wspomniano) przedrukował w swoim wydaniu dedykację, którą Wietor poprzedził w 1532 roku edycję Fortuny. Dedykacja ta miała zniknąć z siedemnastowiecznych wydań. Łazarz jednak utrzymał ją w swojej publikacji, podobnie jak inne elementy należące do ramy wydawniczej, których nie znamy z książek Piątkowskiego i dziedziców Bertutowica. Były to całostronicowy herb Królestwa Polskiego (a zarazem osobisty herb króla) oraz

${ }^{33}$ Książka ta od co najmniej XVII wieku stanowi część bawarskiej kolekcji. Notuje ją już katalog z 1650 roku: „Pollnisch getruckht Buech Fortuna intitulirt in schlecht Pergamen gebunden”, cyt. za: F.G. Kaltwasser, Bibliothek als Museum. Von der Renaissance bis heute, dargestellt am Beispiel der Bayerischen Staatsbibliothek, Wiesbaden 1999, s. 67. 


\section{N E $S$ S $T$ O $R$}

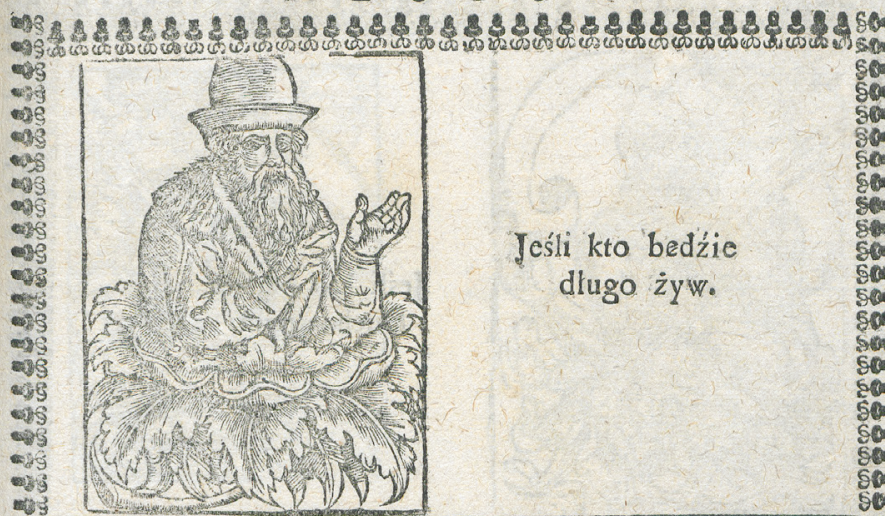

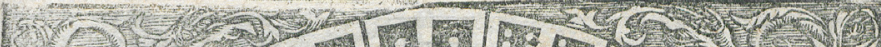

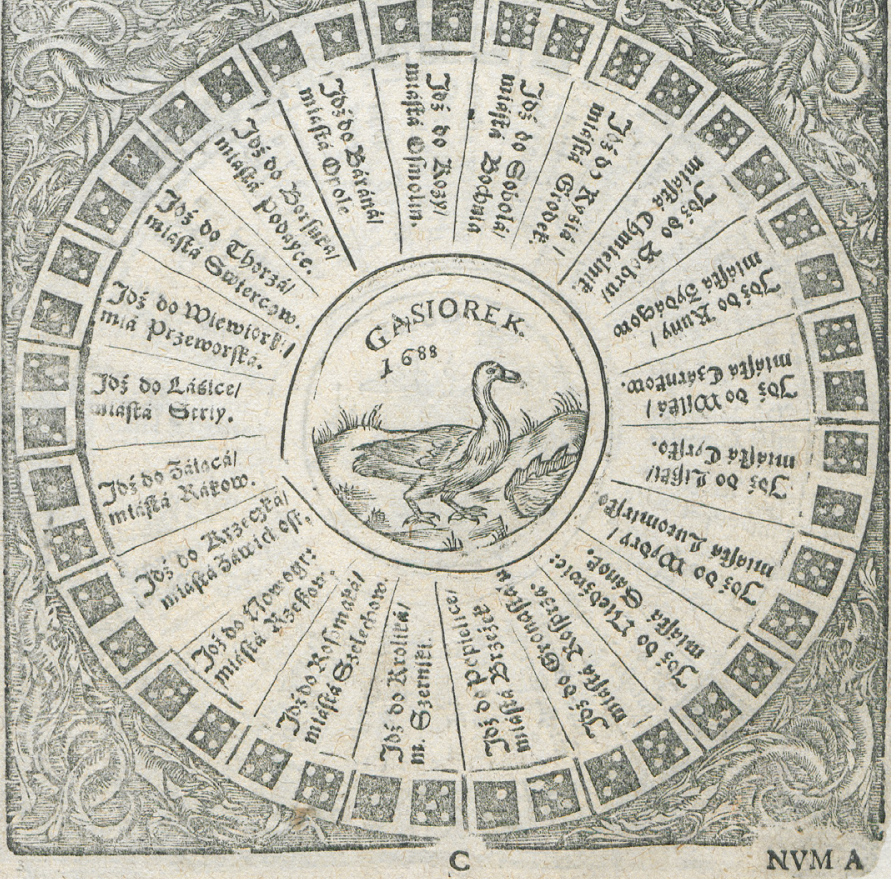

Il. 7. Jan Gawiński, Fortuna albo Szczęście, Kraków: Michał Dyjaszewski, 1744 (Biblioteka Narodowa, Warszawa, sygn. XVIII.3.5734) 


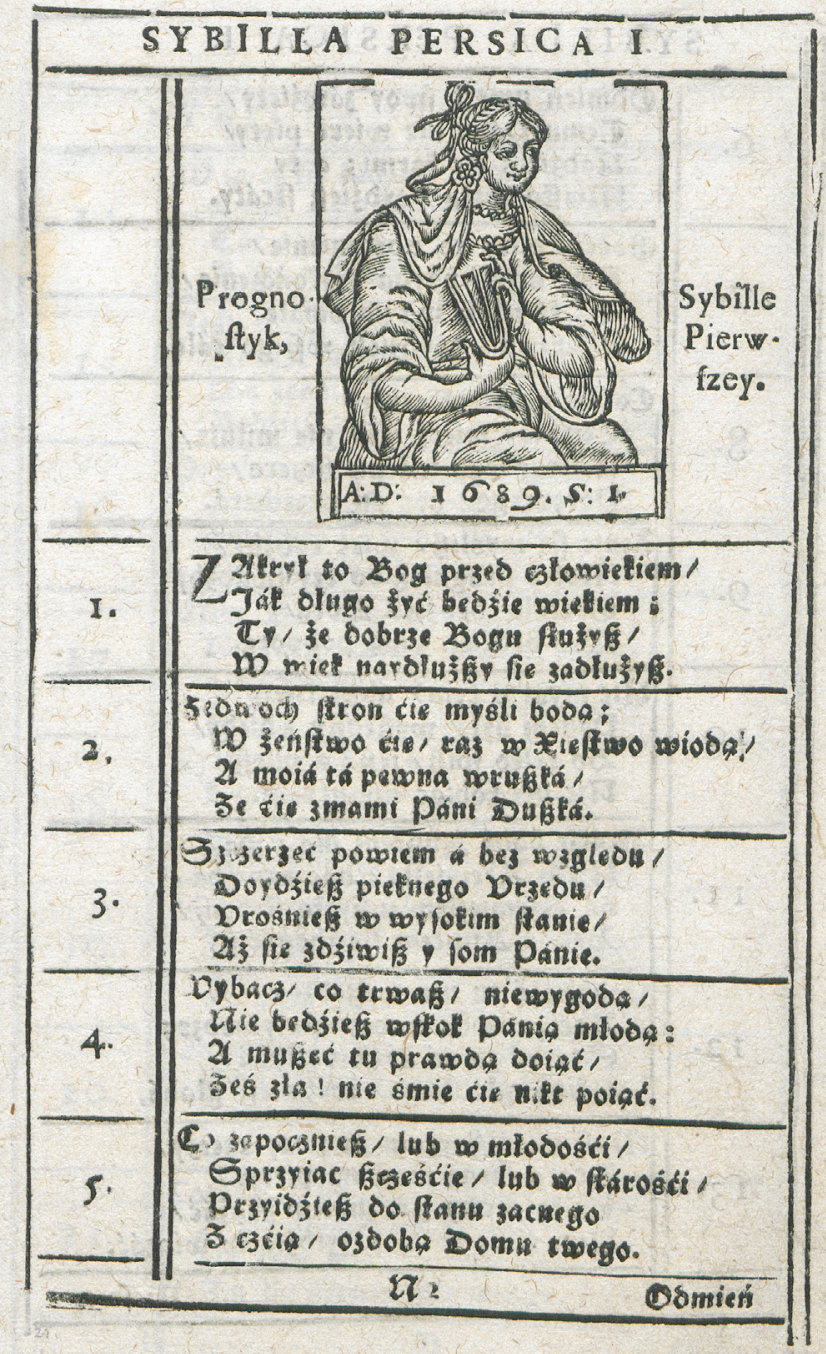

Il. 8. Jan Gawiński, Fortuna albo Szczęście, Kraków: Michał Dyjaszewski, 1744 (Biblioteka Narodowa, Warszawa, sygn. XVIII.3.5734) 
wizerunek herbu Łodzia z inicjałami P.O., które wskazują pewnie na Piotra Opalińskiego, sekretarza Zygmunta Starego, ochmistrza dworu Zygmunta Augusta, kasztelana gnieźnieńskiego. Edycja Łazarza świadczy także o tym, że pierwotnie funkcję strony tytułowej otwierającej kolekcję Kleryki pełniła strona z przedstawieniem Fortuny i wytłoczonym nad drzeworytem tytułem pracy (il. 10). Strona tytułowa znana z publikacji z 1665 roku (z adresem wydawniczym, sygnetem drukarskim, okolona ornamentalną ramką) to już owoc ewolucji pierwszego paratekstowego elementu edycji, z którym stykał się czytelnik dawnej książki.

Kształt edytorski Fortuny Łazarza różni się także od siedemnastowiecznych realizacji w jednym istotnym względzie - czcionką gotycką użytą do jej wytłoczenia była nie szwabacha (jak u Piątkowskiego i dziedziców Bertutowica), ale fraktura (il. 11). Pod tym względem Fortuna Łazarza zapewne bliższa była editio princeps Wietora. Wietor tłoczył ozdobną frakturą polskie książki, także „najpiękniejszy druk oficyny”, Żywot Pana Jezu Krysta Baltazara Opecia z 1522 roku. Łazarz jako pisma tekstowego w obszernych polskich pracach używał szwabachy (obecnej w drukach Wietora od lat 30. XVI wieku), frakturą składając nagłówki i wyróżnienia ${ }^{34}$. Wydaje się więc, że użycie fraktury jako pisma tekstowego w Fortunie, odbitej nie wcześniej niż w latach 60., było echem konwencji znanej z druku Wietora: fraktura była mniej czytelna niż szwabacha, zastosowanie jej było rozwiązaniem gorszym pod względem funkcjonalnym, mimo wszystko Andrysowic jej użył, idąc za zastanym wzorcem.

Przy tym wszystkim przyznać jednak trzeba, że opracowanie typograficzne i graficzne dwóch znanych nam edycji z XVII stulecia do złudzenia przypomina Fortunę, którą „Łazarz Andrysowic drukował", a której kształt edytorski na pewno bliższy był editio princeps

${ }^{34}$ Jedyne druki Łazarza z frakturą jako pismem tekstowym (które udało mi się odnaleźć) to drobne publikacje z lat 50. XVI wieku: pieśni z kancjonału puławskiego z 1550 roku i Tragedyja żebracza z roku 1552. O „walce o pierwszeństwo” między frakturą i szwabachą w drukach z Królestwa Polskiego zob. K. Piekarski, Książka w Polsce XV i XVI wieku, Kraków 1931, s. 12. 
niż wydania Piątkowskiego i Bertutowiców. Struktura kolekcji została utrzymana, większość drzeworytów pojawia się w tych samych miejscach we wszystkich trzech wydaniach, a jeżeli znikają, to zastępują je albo ilustracje mające imitować zużyte klocki, albo obrazki wyszukane w zasobach poszczególnych warsztatów, uzupełniające skład według dawnego wzoru. Nawet jeśli pojawiają się modyfikacje składu, różnice w ozdobności inicjałów i listew czy w szczegółowych propozycjach ich zastosowania, schemat wizualnego opracowania kolejnych stron tomu pozostaje niezmieniony. Jest to widoczne tak na stronach, które zdominował materiał ilustracyjny, jak w drugiej części książki, gdzie wytłoczono proroctwa Sybilli. Choć Łazarz składał wierszyki frakturą, krojem ozdobniejszym niż szwabacha, wydłużonym, uzyskując kolumnę pisma bardziej zaczernioną, już w jego edycji - co najmniej 70 lat starszej niż książka Piątkowskiego i około 100 lat wcześniejszej niż kolekcja z 1665 roku - ponumerowane wiersze okalają linijne ramki, a wizerunki Sybilli patronujących poszczególnym częściom zbioru wróżb odbito, wyśrodkowując drzeworyt i „powiększając” ilustrację za pomocą ornamentalnych listew.

Fortuna z warsztatu Łazarza to jeszcze jeden świadek kształtu edytorskiego, jaki polskiej „książce losów” nadano w 1532 roku w oficynie Hieronima Wietora. Edycja Andrysowica jest świadkiem bardziej wiarygodnym i bliższym chronologicznie pierwodrukowi niż realizacje Piątkowskiego i dziedziców Bertutowica. Zestawienie jej z późniejszymi edycjami Fortuny potwierdza hipotezę o istnieniu wśród zachowanych do naszych czasów starych druków wydawniczych skamielin, na podstawie których rekonstruować można postać (tekstową, ale i wydawniczą) książek zaginionych.

Uwagę badaczy przyciągają przede wszystkim innowacje wprowadzane przez dawnych drukarzy i prowadzone przez nich poszukiwania nowych rozwiązań technicznych i wizualnych. Warto jednak zwrócić uwagę także na książki dokumentujące konserwatyzm typografów - takie jak Fortuna. Zachowawcze wybory dawnych drukarzy mogły mieć rozmaite motywacje, ale wydaje się, że najważniejszą był pragmatyzm producentów książek: naśladując i petryfikując sprawdzone rozwiązania, typograf ułatwiał i przyspieszał pracę warsztatu, 


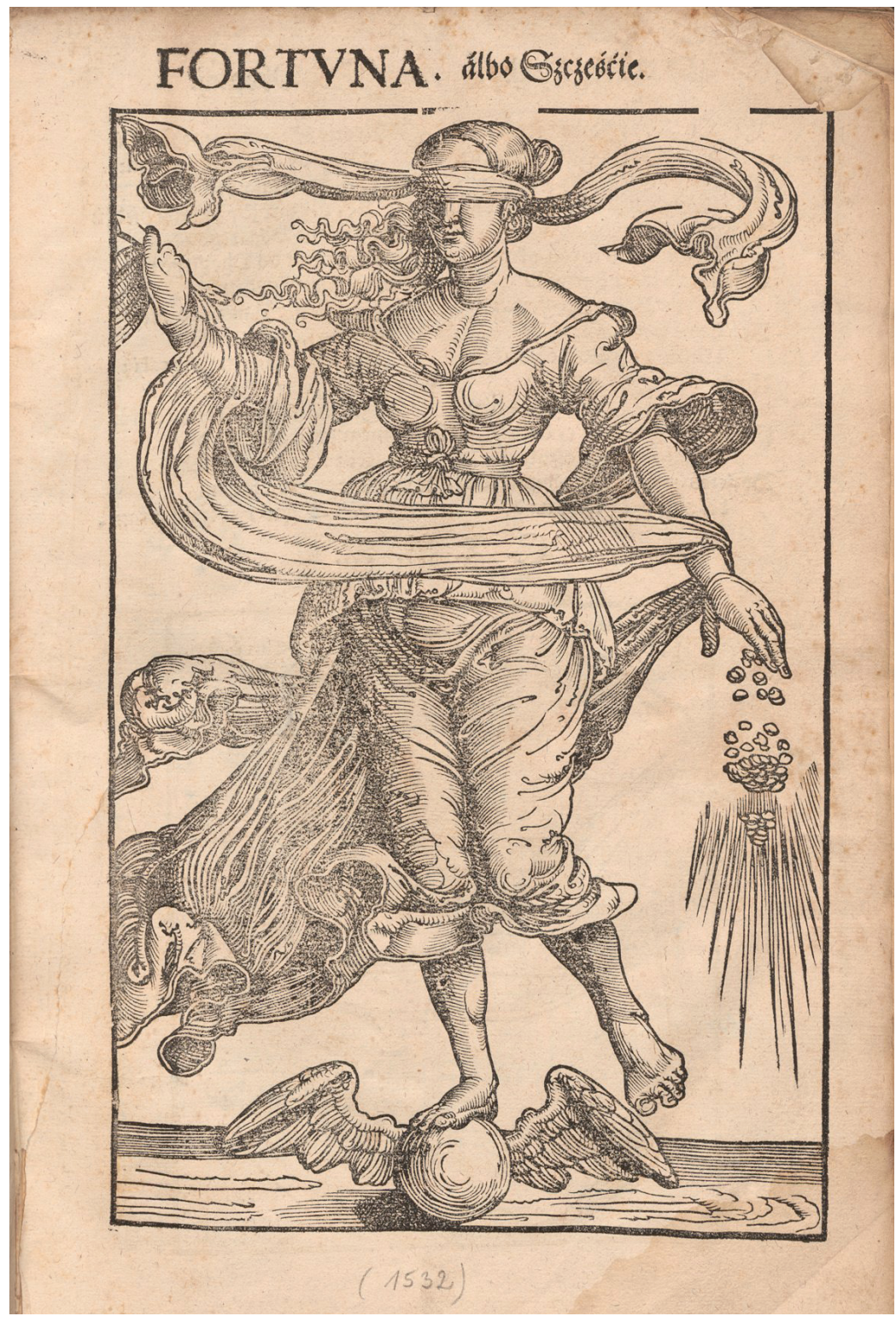

Il. 9. Stanisław z Bochnie, Fortuna albo Szczęście, Kraków: Łazarz Andrysowic [post 1561] (Bayerische Staatsbibliothek, sygn. Res. 2 Phys.m.7) 


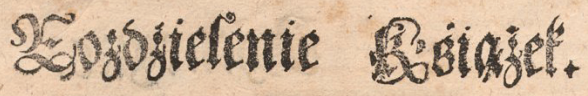

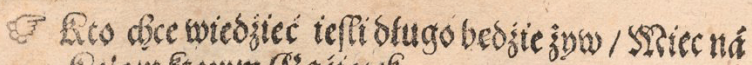

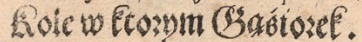

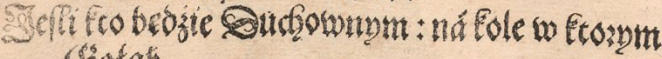
Gotab.

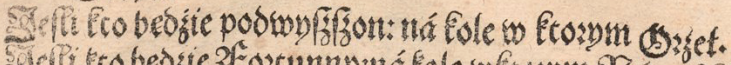

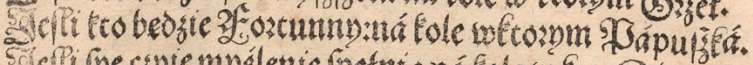

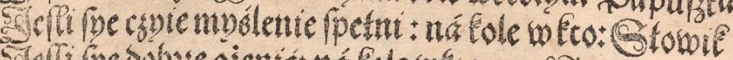

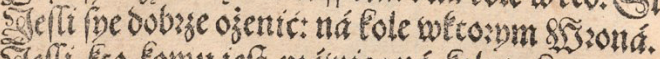
Sglefi tro fomu teft piátwic: ná fole to frosym Gunto. gaárticá.

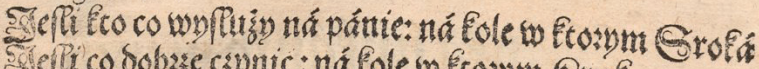

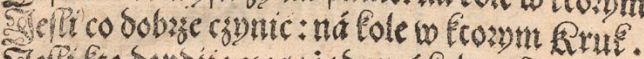

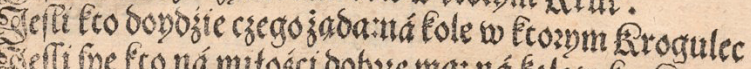

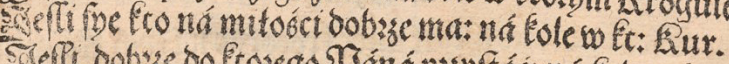

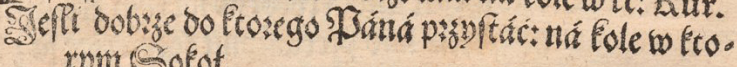
rmm Solot.

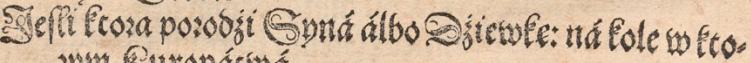
3ym Riuropáción.

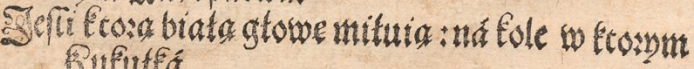
Rututé.

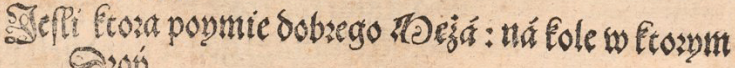

e.oṕ.

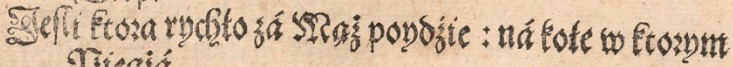

Tiegáá.

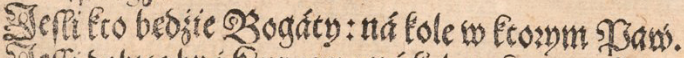

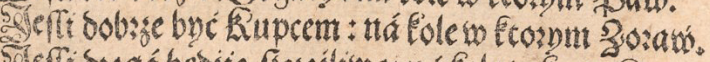

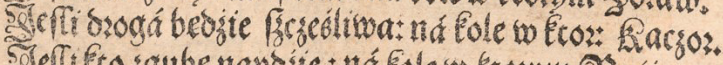

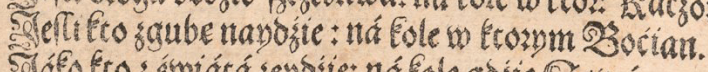

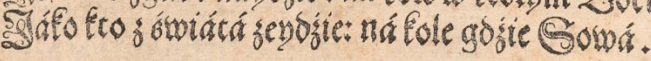

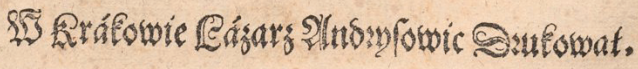

Il. 10. Stanisław z Bochnie, Fortuna albo Szczęście, Kraków: Łazarz Andrysowic [post 1561] (Bayerische Staatsbibliothek, sygn. Res. 2 Phys.m.7) 


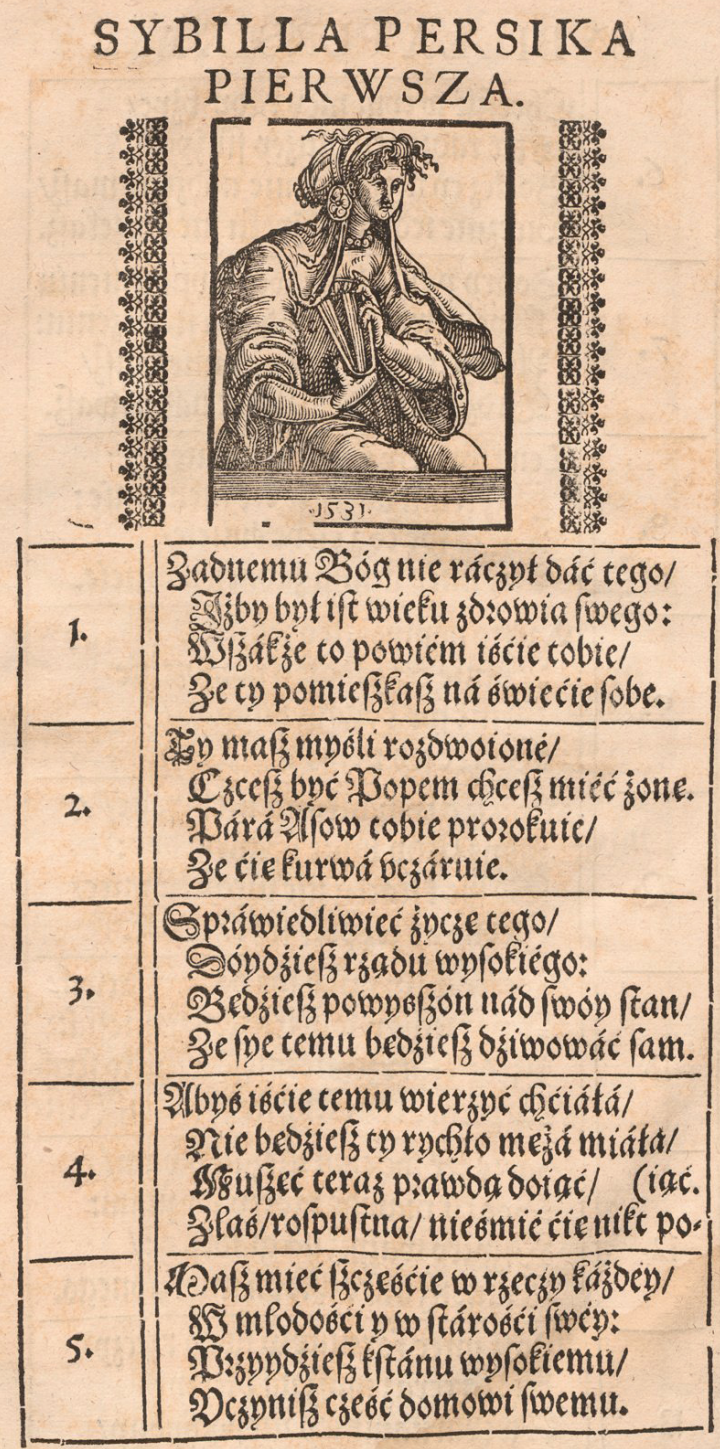

Il. 11. Stanisław z Bochnie, Fortuna albo Szczęście, Kraków: Łazarz Andrysowic [post 1561] (Bayerische Staatsbibliothek, sygn. Res. 2 Phys.m.7) 
ograniczał niebezpieczeństwo popełnienia kosztownego błędu, oszczędzał czas swoich pracowników. Przy produkcji Fortuny innowacje byłyby szczególnie ryzykowne, bo utrzymanie skomplikowanej struktury kolekcji w kształcie, który nadano jej w pierwszym wydaniu, było warunkiem powodzenia gry, a więc czytania czy używania „książki losów” w ogóle. Ważne było przede wszystkim powtórzenie układu treści, ze wskazówkami umożliwiającymi przechodzenie od jednego etapu wróżenia do następnego, i wierne utrzymanie liczbowych zależności między zestawami kół i odpowiedziami Sybilli, bo ich rozbicie pociągnęłoby za sobą żmudne porządkowanie drogi do każdej z ponad czterystu przepowiedni. Warto było także powtórzyć zaproponowane na pewno jeszcze w pierwodruku zestawienia pytań do losu, mitycznych postaci i zwierząt - była to zabawa słowem i obrazem, intelektualny koncept, który podnosił wartość tomu, choć pewnie nie był czytelny dla wszystkich jego użytkowników. Najprostszym rozwiązaniem było przedrukować in extenso pytania, wyniki rzutów kości, nazwy na kołach fortuny i oracula, powtarzając także wizualne ukształtowanie wcześniejszych edycji Fortuny. I tak też czynili producenci książki do wróżb przez wiele dziesięcioleci.

O kształcie edytorskim dawnej polskiej książki wiemy wciąż jeszcze stosunkowo niewiele. Trudno bez badań opartych na szerokiej kwerendzie i analizie statystycznej powtarzanych w wielu wydaniach tytułów lub typów publikacji powiedzieć, czy podobny tradycjonalizm cechował produkcję wydawniczą Rzeczypospolitej w ogóle, czy może dotyczył niektórych tylko książek ${ }^{35}$. Sądzę jednak, że przynajmniej

35 Podobne badania postuluje się już od jakiegoś czasu (zob. np. A. Żbikowska-Migoń, O potrzebie badań nad kształtem edytorskim polskiej książki naukowej XVIII-XIX wieku z perspektywy funkcjonalności publikacji, w: Od książki dawnej do biblioteki wirtualnej - przeobrażenia bibliologii polskiej, red. D. Degen, M. Fedorowicz, Toruń 2009, s. 165-186). W ostatnich latach pojawiło się kilka wartościowych studiów poświęconych konwencjom wydawniczym, kształtowi edytorskiemu, typografii czy „architekturze dawnej książki”. Na przykład: K. Socha, Ewolucja dawnej typografii w „Żywotach świętych” - podejście funkcjonalne, w: Nad spuścizną Piotra Skargi, red. J.S. Gruchała, Kraków 2012, s. 46-186; M. Komorowska, Kształt edytorski postylli polskich XVI-XVII wieku - w poszukiwaniu staropolskich konwencji 
drukarzy tłoczących powtarzane wydania książek popularnych, poszukiwanych przez czytelników, a zarazem wymagających uwagi jako „projekty wydawnicze”, można podejrzewać o postawy zachowawcze, ciążenie ku zastanym wzorcom. Przy produkcji książki o znacznej objętości, wieloelementowej budowie, bogato ilustrowanej konserwatyzm edytorski mógł okazać się najlepszą strategią, jaką obrać potrafił drukarz tłoczący jej kolejne wydanie.

\section{Bibliografia}

Borsa G., A „Fortuna” sorsvetökönyv eredete és utóelete, w: idem, Könyvtörténeti írások I. A hazai nyomdászat 15-17 század, Budapest 1996, s. 301-306.

Borsa G., Alte siebenbürgische Drucke (16. Jahrhundert), Köln 1996.

Borsa G., Hol és mikor nyomták az eddig ismert két legrégibb magyar sorsvetö könyvet?, w: idem, Könyvtörténeti írások I. A hazai nyomdászat 15-17 század, Budapest 1996, s. 295-300.

Chemperek D., Poezja Jana Gawińskiego i kultura literacka drugiej połowy XVII wieku, Lublin 2005, s. 323-336.

Chmiel A., Inwentarz rzeczy introligatora krakowskiego Macieja Przywilckiego z roku 1587, „Silva Rerum” 4 (1928), s. 175-180.

Chojecka E., O tematach i formach antykizujacych w grafice polskiej XVI wieku, „Biuletyn Historii Sztuki” 32 (1970), nr 1, s. 19-37.

Chojecka E., Związki artystyczne polskiego drzeworytu renesansowego z grafika europejską. Kryspin $i$ Wendel Szarffenbergowie (Acta Universitatis Wratislaviensis, no. 364, Bibliotekoznawstwo, t. 7), Wrocław 1978, s. 181-193.

Genette G., Paratexts. Thresholds of interpretation, trans. J.E. Lewin, Cambridge 1997. Gingerich O., Ksiązka, której nikt nie przeczytał, przeł. J. Włodarczyk, Warszawa 2004. Green J., Databases, Book Survival and Early Printing, „Wolfenbütteler Notizen zur Buchgeschichte" 40 (2015), s. 35-47.

Green J., McIntyre F., Lost Incunable Editions. Closing in on an Estimate, w: Lost Books. Reconstructing the Print World of Pre-Industrial Europe, ed. F. Bruni, A. Pettegree, Leiden 2016, s. 55-72.

wydawniczych, „Terminus” 17 (2015), z. 3 (36), s. 317-367; A. Kocot, Artyści „czarnej sztuki". Typografia druków Floriana Unglera i Macieja Wirzbięty (Bibliotheca Iagellonica. Fontes et Studia, t. 26), Kraków 2015; K. Socha, Typografia publikacji pochodzących z drukarń Uniwersytetu Jagiellońskiego, 1674-1819, Kraków 2016. 
Green J., McIntyre F., Needham P., The Shape of Incunable Survival and Statistical Estimation of Lost Editions, „The Papers of the Bibliographical Society of America" 105 (2011), no. 2, s. 141-175.

Harris N., Marin Sanudo, Forerunner of Melzi, part 1, „La Bibliofilia” (1993), s. 12-29.

Kaltwasser F.G., Bibliothek als Museum. Von der Renaissance bis heute, dargestellt am Beispiel der Bayerischen Staatsbibliothek, Wiesbaden 1999.

Kapełuś H., Stanisław z Bochnie, kleryka królewski (Studia Staropolskie, t. 13), Wrocław 1964.

Kapełuś H., Ślaski J., Polski druk popularny na Węrzech. Z dziejów „Fortuny”, „Rocznik Biblioteki Narodowej” 2 (1966), s. 297-317.

Kawecka-Gryczowa A., Ariańskie oficyny wydawnicze Rodeckiego i Sternackiego. Dzieje i bibliografia, Wrocław 1974.

Kiliańczyk-Zięba J., The Book Inventory of the Sixteenth-Century Krakow Bookbinder, Maciej Przywilcki, w: Documenting the Early Modern Book World: Inventories and Catalogues in Manuscript and Print, ed. M. Walsby, N. Constantinidou, Leiden 2013, s. 263-282.

Kiliańczyk-Zięba J., In Search of Lost Fortuna. Reconstructing the Publishing History of the Polish Book of Fortune-Telling, w: Lost Books. Reconstructing the Print World of Pre-Industrial Europe, ed. F. Bruni, A. Pettegree, Leiden 2016, s. 120-143.

Kocot A., Artyści „czarnej sztuki”. Typografia druków Floriana Unglera i Macieja Wirzbięty (Bibliotheca Iagellonica. Fontes et Studia, t. 26), Kraków 2015.

Komorowska M., Kształt edytorski postylli polskich XVI-XVII wieku - w poszukiwaniu staropolskich konwencji wydawniczych, „Terminus” 17 (2015), z. 3 (36), s. 317-367.

Kracik J., Jan Kubiński - nieznany typograf krakowski XVII wieku?, „Biuletyn Biblioteki Jagiellońskiej” 39 (1989), s. 13-16.

Lewicka-Kamińska A., Inwentarz ksiegarni Andrzeja Cichończyka w Jarosławiu $z$ r. 1621, „Roczniki Biblioteczne” 5 (1961), s. 253-299.

Mańkowska A., Kawecka-Gryczowa A., Wietor Hieronim, w: Drukarze dawnej Polski od XV do XVIII wieku, t. 1: Małopolska, cz. 1: Wiek XV-XVI, red. A. Kawecka-Gryczowa, Wrocław 1983, s. 350-357.

Margócsy D., Somos M., Joffe S.N., The Fabrica of Andreas Vesalius. A Worldwide Descriptive Census, Ownership, and Annotations of the 1543 and 1555 Editions, Leiden 2018.

Marinis T. de, Le illustrazioni per il libro de le sorte di Lorenzo Spirito, w: idem, Appunti e ricerche bibliografiche, Milano 1940, s. 69-83.

Needham P., The Late Use of Incunables and the Paths of Book Survival, „Wolfenbütteler Notizen zur Buchgeschichte" 29 (2004), no 2, s. 35-59.

Ocieczek R., O różnych aspektach badań literackiej ramy wydawniczej w książkach dawnych, w: O literackiej ramie wydawniczej w ksiażkach dawnych, red. R. Ocieczek, Katowice 1990, s. 7-20.

Otwinowski E., Pisma poetyckie, wyd. P. Wilczek (Biblioteka Pisarzy Staropolskich, t. 15), Warszawa 1999. 
Pauli Ż., Wiadomości o życiu i pismach Jana z Wielomowic Gawińskiego, w: Poezje Jana $z$ Wielomowic Gawińskiego, wyd. Ż. Pauli, Lwów 1843.

Piekarski K., Fragmenty czterech nieznanych wydań „Marchołta”, „Pamiętnik Literacki” 32 (1935), s. 481-520.

Piekarski K., Fragmenty dwu zaginionych dialogów Mikołaja Reja, „Przegląd Współczesny" 6 (1923), $\mathrm{nr} 15$, s. 1-16.

Piekarski K., Książka w Polsce XV i XVI wieku, Kraków 1931.

Proot G., Survival Factors in Seventeenth-Century Hand-Press Books Published in the Southern Netherlands. The Importance of Sheet Counts, Sammelbände and the Role of Institutional Collections, w: Lost Books. Reconstructing the Print World of Pre-Industrial Europe, ed. F. Bruni, A. Pettegree, Leiden 2016, s. 160-201.

Reske Ch., Die Produktion der Schedelschen Weltchronik in Nürnberg $=$ The Production of Schedel's Nuremberg Chronicle, Wiesbaden 2000.

Różycki E., Inwentarz książek kuśnierza Wojciecha Charajowicza ze Lwowa z początku XVII wieku, „Roczniki Biblioteczne” 36 (1992), z. 1-2, s. 267-278.

Socha K., Ewolucja dawnej typografii w „Żywotach świętych” - podejście funkcjonalne, w: Nad spuścizną Piotra Skargi, red. J.S. Gruchała, Kraków 2012, s. 46-186.

Socha K., Typografia publikacji pochodzacych $z$ drukarń Uniwersytetu Jagiellońskiego, 1674-1819, Kraków 2016.

Sokolski J., Bogini, pojęcie, demon. Fortuna w dziełach autorów staropolskich, Wrocław 1996.

Sokolski J., „Fortuna radzi...”, czyli uwagi o dwóch fraszkach Jana Kochanowskiego, „Pamiętnik Literacki” 86 (1995), s. 133-137.

Sokolski J., „Sybilla prorokuje...” O fraszce Do Stanisława $(I, 63)$ Jana Kochanowskiego „Pamiętnik Literacki” 90 (1999), s. 149-152.

Stanisław z Bochnie Gąsiorek, Fortuna abo Szczęście, wyd. J. Kiliańczyk-Zięba, Kraków 2015.

Wirzbięta M., Gospodarstwo dla młodych a nowotnych gospodarzów, przygotował J. Sokolski, Wrocław 1989.

Żbikowska-Migoń A., O potrzebie badań nad kształtem edytorskim polskiej książki naukowej XVIII-XIX wieku z perspektywy funkcjonalności publikacji, w: Od książki dawnej do biblioteki wirtualnej-przeobrażenia bibliologii polskiej, red. D. Degen, M. Fedorowicz, Toruń 2009, s. 165-186. 